NBER WORKING PAPER SERIES

\title{
WHITE HATS OR DON QUIXOTES? HUMAN RIGHTS VIGILANTES IN THE GLOBAL ECONOMY
}

\author{
Kimberly Ann Elliott \\ Richard B. Freeman \\ Working Paper 8102 \\ http://www.nber.org/papers/w8102 \\ NATIONAL BUREAU OF ECONOMIC RESEARCH \\ 1050 Massachusetts Avenue \\ Cambridge, MA 02138 \\ January 2001
}

Prepared for the NBER Conference On Emerging Labor Market Institutions, August 2000; revised Dec 2000. The authors would like to thank Peter Siu, who developed our survey of student activists and interviewed them, as well as provided us with a detailed history of United Students Against Sweatshops. The views expressed herein are those of the authors and not necessarily those of the National Bureau of Economic Research or of the Institute for International Economics.

(C) 2001 by Kimberly Ann Elliott and Richard B. Freeman. All rights reserved. Short sections of text, not to exceed two paragraphs, may be quoted without explicit permission provided that full credit, including (C) notice, is given to the source. 
White Hats or Don Quixotes? Human Rights Vigilantes in the Global Economy Kimberly Ann Elliott and Richard B. Freeman

NBER Working Paper No. 8102

January 2001

\section{ABSTRACT}

With the continuing expansion of global economic integration, labor standards in developing countries have become a hot button issue. One result has been a proliferation of efforts to use the market to put pressure directly on multinational corporations to improve wages and working conditions in their overseas operations and to insist that their suppliers do so as well. This paper analyzes the dynamics of these efforts in terms of a "market for standards" in which consumers, stimulated by human rights activists, demand that corporations improve working conditions in supplier factories. The paper presents evidence that such a consumer demand exists and analyzes the incentives corporations face to respond to it. It examines the nature of the critical intermediary role played by activists in stimulating consumer demands and assesses the outcomes in the major antisweatshop campaigns of the 1990s. The paper also addresses the limitations of such consumer-based campaigns and the concern expressed by some that these activist campaigns may do more harm than good, by deterring investment in and trade with poor countries. It concludes with an overall assessment of when "doing good" actually does good.

Kimberly Ann Elliott

Institute for International Economics

11 Dupont Circle, NW, Suite 620

Washington, DC 20036

kelliott@iie.com
Richard B. Freeman

Harvard University

1050 Massachusetts Ave., 3rd Floor

Cambridge, MA 02138

NBER and LSE

freeman@nber.org 
Labor standards in less developed countries became a hot button issue in discussions of trade and economic development in the 1990s. Standards rose to the top of the public agenda not because workers were unionizing in mass numbers nor because management had turned over a moral leaf nor because the International Labor Organization had asserted itself in the global economy. Labor standards came to the fore because non-governmental groups in advanced countries - the human rights vigilantes of our title - galvanized consumers to demand that multinational firms and their suppliers improve working conditions and pay living wages in developing countries.

How did human rights vigilantes bring labor standards to the center of public discourse? Will the anti-sweatshop activists create a permanent global movement for workers rights or will public interest dissipate over time? Can concerned citizens in advanced countries pressure firms to improve the economic condition of workers in poorer countries or will their activities inadvertently make things worse? Which appellation best characterizes the human rights vigilantes - white hats or Don Quixotes?

We analyze these questions in terms of a "market for standards" in which consumers, stimulated by vigilante intermediaries, demand that corporations improve working conditions in supplier factories. Section 1 presents evidence that a consumer demand for minimum labor standards exists and explores the nature of that demand. Section 2 examines the incentives that exist for firms to respond to this demand and considers how industry structure influences the nature of the response. Section 3 introduces the human rights activists of our title and assesses their role as intermediaries who expose sweatshop abuses and trigger consumers to demand changes in corporate behavior. Section 4 examines the major anti-sweatshop campaigns of the 1990s and their achievements. Section 5 considers the arguments that anti-sweatshop campaigns risk doing more harm than good by raising costs and deterring investment in poor countries; and assesses the limitations of activist consumer-based campaigns. Section 6 concludes with a summary of our conclusions as to when and how human rights vigilante efforts actually do good.

\section{Consumer Demand for Labor Standards}

"[I] had a hard time making up my mind how bad a company had to be before I could bring myself to give its products the old heave-ho." - Joe Queenan, My Goodness 
The sine qua non of activist efforts to improve labor standards around the world is that consumers care about the conditions of the workers who make the items they consume. If consumers do not care or do not associate the conditions with their consumption, human rights vigilantes could not pressure firms to improve working conditions. The extent to which consumers care and their willingness to act on their concerns is, as the above commentator indicates, uncertain. Indeed, many consumers would just as soon not know about poor conditions since that knowledge reduces the utility of their consumption. Activists inform consumers about the conditions of production in ways that resonate with moral concerns, and develop campaigns to turn concern into improvements. From this perspective, the activists are entrepreneurs who identify latent market demands and find ways to meet those demands.

In this section we present survey evidence that consumers care about labor standards and will buy products made under better conditions in preference to those made under worse conditions. That many corporations respond to the activist-induced pressures, at least rhetorically, shows that they believe such a demand exists.

\section{Survey evidence}

You are offered two identical t-shirts with your favorite logo. One was made in good conditions in some third world country. The other was made in a fire-trap factory by people paid near starvation wages. Which $\mathrm{t}$-shirt would you buy ... when the t-shirts cost the same? ... when the shirt made under good conditions costs a bit more?

Surveys that ask questions of this form invariably find that the vast majority of people report they would choose the garment made under better conditions, even if it cost a bit more. Exhibit 1 summarizes the results from surveys undertaken by Marymount University's Center for Ethical Concerns; by the University of Maryland's Program on International Policy Attitudes; and by our project.

The Marymount surveys were conducted in 1995, 1996, and 1999. In each survey, three of four consumers said they would avoid shopping in a store if they knew the goods were produced under bad conditions while not quite two of three say they would be more inclined to shop in stores combating sweatshops. The greater response to knowledge about bad conditions than good conditions suggests that consumers respond more to information that reduces their utility than to information that increases it -- consistent with Kahneman and Tversky's (1979) prospect theory that shows people weigh potential losses more heavily than potential gains. An average 85 percent of respondents in the Marymount 
survey said they would pay $\$ 1$ more for a $\$ 20$ item if they could be assured that it was made under good conditions.

The 1999 Program on International Policy Attitudes (PIPA) survey presented arguments for and against making labor standards part of the trade agenda (University of Maryland 2000). By covering a spectrum of trade-related issues, this survey put attitudes toward labor standards into a broader context. The survey found that most Americans favor linking labor standards to trade. Roughly three of four respondents said they felt a moral obligation to try to help workers faced with poor conditions and approximately the same proportion reported that they would pay $\$ 5$ more for a \$20 garment if they knew it was not made in a sweatshop. ${ }^{1}$ Most respondents found convincing arguments for minimum standards -- that harsh conditions are immoral and that standards eliminate unfair advantage through exploitation -- while far fewer were convinced by arguments against standards -- that they reduce jobs in affected countries and impinge on national sovereignty.

People also differentiated among labor standards. More were concerned about child labor and safe conditions than about the right to unionize. Most consumers did not expect workers in foreign countries to earn US wages (82 percent) and just over half favored lowering trade barriers after being informed about the costs of protectionism. This compares to only 36 percent who favored lowering barriers to clothing imports absent the information. Two-thirds favored free trade as long as society recompensed workers whose livelihood was hurt by trade, say with adjustment assistance and training. Nearly 90 percent said that "free trade is an important goal for the United States, but it should be balanced with other goals, such as protecting workers, the environment, and human rights-even if this may mean slowing the growth of trade and the economy."

Most striking, the largest majority on any trade question (93 percent) agreed that "countries that are part of international trade agreements should be required to maintain minimum standards for working conditions." Thus, Americans support international labor standards in both their private consumption behavior and in the public sphere.

\section{Our survey}

To illuminate further the consumer demand for labor standards, we surveyed a small number of randomly chosen persons in the United States in fall 1999. ${ }^{2}$ The survey used a split sample design that posed different questions to different respondents to see whether responses varied with the wording or presentation of questions. The results parallel those of the Marymount and PIPA surveys. Most 
respondents said that they cared about the treatment of the workers who made the clothing they bought and that they would be willing to pay more for an item if they knew it was made under good working conditions (see exhibit 1). On average, consumers said that they were willing to pay 28 percent more on a $\$ 10$ item and 15 percent more on a $\$ 100$ item (including as zeros consumers who said that they were unwilling to pay extra for the assurance). Eighty-four percent of a different sub-sample said that they would purchase a different t-shirt rather than one "with a nice logo" that local students said was made under poor labor conditions. Nearly two-thirds said that they would not buy the t-shirt made under poor conditions at any price. ${ }^{3}$ The third who said they would buy it if the price was lowered wanted a mean discount of $\$ 4.38$. On the other side, consumers said that they would pay an average of just $\$ 0.87$ for knowing the product was made under good conditions (including 0s for persons who said they would not pay the extra amount, or who refused to answer). ${ }^{4}$ The greater response to the utilityreducing information about bad conditions than to the utility-increasing information about good conditions again fits with prospect theory.

At the heart of any economic analysis of consumer tastes is the demand curve -- the relation between the number of consumers who would buy products at different prices. Our survey allows us to estimate the demand curve for labor standards, taking account of the potential difference in responsiveness to products made under good conditions and those made under bad conditions. We asked some respondents "how much more would you be willing to pay for items made under good working conditions" for items worth $\$ 10$ and $\$ 100$. We asked others if they would buy a $\$ 10$ t-shirt made under poor conditions if its price was lowered to $\$ 9 \ldots 8 \ldots \$ 7 \ldots$, and how much they would pay for the $\mathrm{t}$-shirt if it was made under good conditions.

Panels A-C of Exhibit 2 show that both designs give qualitatively similar results: high elasticities of demand for products made under good conditions but low elasticities of demand for products made under bad conditions. ${ }^{5}$ The willingness to pay for items made under good conditions has elasticities ranging from -3.7 to -4.9 . The 20 percent to 30 percent of consumers who are unwilling to pay anything extra produce an immediate loss in revenue that these estimates indicate cannot recovered by those willing to pay more. In addition, there is a sharp drop-off in purchases as the price of the item rises. By contrast, roughly two of three consumers say they would not buy the item made under bad conditions under any circumstance and the demand for $\mathrm{t}$-shirts produced under bad conditions is inelastic (-0.29) among the third who said they would buy them at a discount. 
The implication is that firms can lose greatly from having their products identified as being made under bad conditions but have only limited space to raise prices for products made under good conditions -- unless consumers see competing products as made under bad conditions. ${ }^{6}$ The differential consumer response to information about good and bad conditions helps explain, we argue later, the behavior of activists and firms in the market for standards.

\section{Do consumers act as they say?}

"I still shop at those brand-name stores, but I feel really guilty about it." Founding member of a New York City high school Student Committee Against Labor Exploitation (Business Week, September 11, 2000)

Readers may question whether people will do what they say on a survey. Economists want to see behavior not intentions. The best way to find out how many people would in fact pay extra for a product made under good conditions is to conduct a "Standards Experiment," by offering the product for sale along side a similar product with no or negative information on working conditions, and seeing what happens. Unfortunately, no one has done this. ${ }^{7}$ But experimental data and market behavior in other domains suggests that people care enough about the conditions of others to behave as they say they would in the surveys.

The Dictator's Game is perhaps the experimental economics game closest to the standards problem. Two players are given envelopes. One has $\$ 100$ in it while the other envelope has $\$ 0$. The person with the $\$ 100$ can simply keep the money and say tough kazoo to the person who got $\$ 0$. The economically rational decision is to do just that. But behavior is different. Only about 20 percent of players keep all the money. The vast majority share some with their unlucky partner, albeit offering less than if the second player could veto the division (as in the "Ultimatum Game"). Another game that comes close to the standards problem is the Lost Wallet Game (Charness, Haruvy, and Sonsino 2000). One person finds a wallet, which has more value to its owner than to the finder. The owner may or may not give a reward for finding the wallet. The greater the value of the wallet to the owner relative to the finder, the more likely is it that the finder will return it, even though this will mean less money than if the finder kept the wallet. The implication is that people gain some utility from being "fair" to someone who values something more than themselves. ${ }^{8}$ Thus, at least in laboratory situations, people behave in ways that lend believability to the responses from surveys on standards and purchasing behavior. 
Going outside the laboratory, the fact that people contribute to charity and volunteer time for charitable activities shows that they sacrifice income for social goals. Charitable giving and volunteering is greater in the US than in other advanced countries, presumably because the US does not have a large welfare state. In the charitable sector, moreover, much giving and volunteering comes in response to requests from activists (Freeman 1997). Again, people behave as if they care for more than their own immediate consumption and thus could be expected to consider labor standards in their purchase of goods, as they say they would in surveys.

Finally, the response of many companies to allegations of worker mistreatment also suggests that consumers act in accord with survey responses. If consumers did not care about conditions, firms would simply ignore the allegations as irrelevant to their bottom lines. Firm behavior is also consistent with the finding that consumer demand for good and bad conditions is asymmetric since, as we will document shortly, firms rarely address labor standards issues unless forced to do so by bad publicity. Inelastic consumer demand for goods produced under abusive conditions gives companies an incentive to respond to negative publicity, elastic demand for "worker-friendly" products means that firms see little advantage in marketing their products on that basis unless it costs them little or nothing to do so.

\section{Firms and the Market for Labor Standards}

"Their image is everything. They live or die by their image. That gives you a certain power over them."--Charles Kernaghan, National Labor Committee (The New York Times, June 18, 1996)

Some well-known firms have responded to activist campaigns alleging that they or their subcontractors mistreat workers. Levi's adopted the first code addressing sweatshop issues after allegations of abuse among its suppliers in Saipan. Wal-Mart followed after its products were linked to child labor in Bangladesh. Nike initially rejected responsibility for conditions in its supplier factories but then took steps to improve conditions in order to blunt unceasing criticism from activists. Alternatively, Reebok has tried to avoid being tarred by the same brush as Nike by creating a human rights award to honor activists fighting for democracy and against child labor and other abuses. Critics argue that Reebok is hypocritical and has done little to upgrade working conditions in its factories but, so far, the strategy has worked since activists have not targeted Reebok as aggressively as they have Nike.

Allegations of sweatshop abuse generally arise in the apparel and footwear sectors, which are labor-intensive, geographically mobile, and highly price-competitive (ILO 2000). Companies in these 
sectors focus on product design and marketing, while contracting out most or all of the actual production. Large retailers with a prominent market presence, such as Wal-Mart and The Gap, or firms with high brand name recognition and recognizable logos, such as Nike and Levi's, are the most vulnerable to activist campaigns since they sell their "image", which can be tarnished by campaigns. Indeed, Klein (1999) argues that these companies are the victims of their own success because they increasingly base their marketing not on the utility of the products they sell, but on the "statement" the product makes about the person consuming it. In addition, many of the targeted firms market heavily to teenagers and young adults, where demand for branded clothing and footwear is often faddish. No one wants the statement they make by wearing Nike shoes or Gap jeans to be that they are indifferent to young women their age or younger slaving in a stifling factory for 12 hours a day. If it becomes gauche to wear a given label's apparel because it was made in a sweatshop, retailers could lose sales quickly. Nor does it matter to the corporation whether the motivation is genuine concern for the workers who make the product or simply the desire to be cool with one's friends. In either case, "Brand image, the source of so much corporate wealth, is also, it turns out, the corporate Achilles' heel" (Klein 1999, 343).

The move to "lean retailing" also affects the corporate response to anti-sweatshop campaigns. The apparel industry has gone lean, holding low inventories of existing products and using information technology to tailor items to market preferences as quickly possible (Weil 2000). This makes potential supply disruptions, say because of revelations of child labor in a contract facility, especially costly to firms. The premium on speed and the advantages of the North American Free Trade Agreement and other hemispheric trade preferences has led US apparel firms to source more production in Mexico, the Caribbean, and Central America., which also makes it easier for activists to uncover abuses.

Offsetting the incentives to act pre-emptively are the costs of enforcing higher labor standards, which the consumer surveys suggest will be difficult to fully pass on. In addition to any direct costs of improving working conditions, the US retailer must also pay for monitoring compliance throughout its supply chain. That means monitoring thousands of contractors around the world, who may, in turn, subcontract jobs to thousands more, including home workers in some cases. Exhibit 3 shows the chain of production for infant and children's apparel between one US retailer, JC Penney, and workers in one country, the Philippines. Through this chain JC Penney contracts with over 2,000 suppliers in more than 80 countries. And this is not unusual. Nordstrom has over 50,000 contractors and subcontractors, 
while the National Labor Committee estimates that Walmart has used 1,000 factories just in China and that Disney licenses products in over 30,000 factories around the world.

\section{The firm's response to campaigns}

Given an anti-sweatshop campaign, how will a profit-maximizing retailer or marketer respond? ${ }^{9}$ Absent a campaign, we assume that the firm cares nothing about labor standards and leaves it to the contractor to balance the costs of improved work conditions against the potential productivity gains. This gives the starting level of standards So. An activist campaign forces firms to re-assess the costs of supplying standards against the potential loss of consumer demand. Increasing standards means that the firm will require contractors to abide by a code of higher minimum standards and monitor compliance.

Exhibit 4 shows how a campaign can change the price that consumers will pay for a product, and the cost per unit of product of raising standards to different levels. Absent a campaign to inform consumers about conditions, the firm charges Po while producing at base level standards So. A campaign that fails to engage consumers, such as the unsuccessful effort against Disney, leaves the price unchanged. By contrast, a successful campaign reduces the price the firm gets for producing under bad conditions and raises the price if they produce under good conditions. On the basis of our survey results, we assume that the slope of the price curve is kinked around the level of standards, $\mathrm{S}^{*}$, that consumers would accept. Firms suffer large reductions in price for below-S* standards but gain only modestly from above- $\mathrm{S}^{*}$ standards.

Given the new price curve that the campaign has produced, the firm will assess the benefits and costs of raising standards. In the exhibit the cost curve starts at 0 and then rises linearly. The firm maximizes profits by picking the level of standards where the price received for the good inclusive of standards most exceeds the cost of standards. With curve $\mathrm{C} 1$, the costs of improving standards are so high they cannot be recovered so the firm will not raise standards. In this situation the activist campaign has failed in two ways. It has failed to raise standards and it has probably reduced the employment or earnings of workers in contract facilities because the firm will reduce orders since it makes less money.

With cost curve $\mathrm{C} 2$, by contrast, the maximum profit occurs at the kink point. ${ }^{10}$ The campaign has attained its goal $S^{*}$ by presenting the firm with a stark choice: fail to meet $S^{*}$ and suffer price cuts to sell the same amount (or alternatively, suffer reductions in sales at the same price) or enforce higher standards throughout their supply chain with only modest possible gains in price. 
Finally, with cost curve $\mathrm{C} 3$, the firm will produce standards in excess of the kink point. Here the marginal cost of standards is so modest that the firm can potentially make more money by producing high standards than it did before the campaign. For example, a firm that improved health and safety among its suppliers, as Nike and Reebok did by moving to water-based adhesives in shoe production, might publicize this in its advertisements, potentially gaining extra sales while also lowering injury rates and improving worker effort or morale.

The diagram directs attention to three determinants of the success of activist campaigns: the cost of producing the standards; the level of standards at which the price curve changes shape; and the twist in the price schedule when consumer concerns are stimulated. The asymmetry in demand reflected in the price schedule explains why activists emphasize transparency of information while firms try to control information about conditions as tightly as possible. Information about bad conditions is highly costly, while information about good conditions raises revenues only modestly. This means that full disclosure of the location of plants and independent monitoring of compliance with standards become issues of conflict. If consumers responded more to information about good conditions, activists and firms would have common ground on which to work.

The model also highlights the dilemma activists face in their campaigns. On one side, to rouse interest, activists must highlight the evils of low labor standards and stress how far current standards are from $\mathrm{S}^{*}$, or some higher value the activists seek. On the other side, they need business and governments to improve conditions, which requires some compromise with these groups. If activists are too moderate or compromise too readily, they will not gain the support of consumers. But if their demands are too radical, they will alienate business and government. By being either too " activists can fail, since in either case firms will get greater profit from maintaining standards than from working with suppliers to upgrade them.

In sum, consumer demand for labor standards represents concerns that can readily show up in the marketplace. But since consumers have no direct information about the conditions of work, their demand for standards is a latent one that would typically remain beneath the surface but for the work of the human rights vigilantes. The vigilante activists are catalytic agents, stimulating consumers through their campaigns, and pressuring firms to improve conditions. Without them, there would be no antisweatshop movement.

\section{Who Are the Vigilantes?}


"And who appointed you to defend the workers making sneakers for my firm or the consumers of my sneakers?" - Business executive facing student anti-sweatshop campaign

Human rights vigilantes are self-appointed advocates, motivated by moral concerns, rather than elected representatives of workers or consumers. They are a varied group, with differing expertise and modes of operation. In a 1999 directory of US anti-sweatshop organizations, Global Exchange listed 40 different groups involved in anti-sweatshop campaigns in the United States. Web search yielded several additional groups, including some outside the clothing area (coffee farmers, rug makers), as well as groups outside the United States. A more extensive search would undoubtedly yield many more.

Appendix A lists 43 US-based groups identified from these sources. Most are small rather than mass membership organizations, and most are relatively new. Slightly more than half were formed in the 1990s and nearly 80 percent have existed only since 1980. Most groups concentrate on a particular group of workers, either geographically, ethnically, or by industry or company. Some groups started as anti-apartheid campaigners while several formed to protest human rights abuses and American policy toward repressive regimes in Central American. For these groups, anti-sweatshop campaigns are the next phase in their fight for peace and social justice.

The groups constitute an ecology with varying orientations from moderate to militant. Some have a religious base -- the Interfaith Center for Corporate Responsibility, which was a key actor in the efforts to reduce foreign investment in South Africa, and the NY State Labor-Religion Coalition are cases in point. Others, such as the National Labor Committee (NLC) and United Students Against Sweatshops (USAS), have an activist-left orientation. Yet others such as Verite, an organization that monitors conditions of subcontractors for firms, or Co-op America, are apolitical do-gooders. As the groups vary along many dimensions, the classification in Appendix A is by no means perfect.

These organizations also play a variety of roles in the "market for standards." Some, like Corporate Watch or Jeff Ballinger's Press for Change, focus on providing information about abuses. Some seek out other key players to negotiate standards and a few provide monitoring services. Some groups are vertically integrated, like the Council on Economic Priorities, which negotiated a standard with various stakeholders and created an agency to oversee enforcement, and the International Labor Rights Fund, which plays a role in all three functions.

Morton Winston (forthcoming) of the College of New Jersey and Amnesty International has categorized the groups into Confronters - who take a confrontational and adversarial approach to corporations in the belief that only the threat of reduced profits will induce them to improve conditions; 
and Engagers, who seek to persuade firms to do "the right thing". While the two groups often appear to be at loggerheads, in fact both are necessary for the market for standards to function. Confronters keep consumers riled up with their exposes, and gain support by generating strong campaigns. But they cannot readily compromise with firms. Engagers broker agreements with firms but lose credibility by compromising with "the enemy". Without the confronters, firms, governments, and international agencies could easily ignore moderate desires for improved standadrds. Without the moderates firms, governments, and agencies would declare it impossible to meet militant demands and would reject them out of hand.

Thus, we have a classic mixed strategy type game. In equilibrium, there should be an evolutionarily stable strategy division of activists between the two groups. When the marginal return to confrontation is higher, more activists should adopt a confrontation strategy; when the marginal return to engagement is higher, more activists should adopt strategy until the marginal returns from each are equated. In the current phase of the movement, however, Winston (forthcoming) points to the risk of a backlash among corporations if confronters refuse to recognize progress, relentlessly criticize corporations that inevitably fall short, and "ensure that no good deed goes unpunished." Fear of becoming a target can then deter a company from taking even the first steps -- adopting a code or allowing external monitoring.

Among confronters, the NLC has been highly effective due to the skills of Charles Kernaghan and to luck in the form of the Kathie Lee Gifford case, which we summarize shortly. Global Exchange has also generated considerable media attention with its campaigns. In terms of providing "muscle" for campaigns, church and student groups are the most important. Religious groups link anti-sweat activities to congregations while the United Students Against Sweatshops (USAS) has spurred students around the country to protest poor labor standards related to college licensed products. Student activism has in fact taken center-stage in the anti-sweatshop movement, as USAS has successfully pressured companies to make public the names and locations of subcontractors and spearheaded the Worker Rights Consortium.

\section{The student activists}

"Clothing bearing our university logos ought to be produced under healthy, safe and fair working conditions" USAS, College Clothes From the Concrete Prison, July 1999, p 1 
The growth of anti-sweatshop activism among students has been sudden and sharp - an example of the spurt phenomenon that often characterizes social movements (Freeman 1999). In 1995 there was no student anti-sweatshop movement in the United States. The AFL-CIO's first Union Summer in 1996 generated some student interest, but it was the United Needle and Textile Workers Union (UNITE) that did most to catalyze student anti-sweatshop activity. UNITE hired a young bachelor's graduate, Ginny Coughlin, to coordinate their anti-sweatshop activity in 1995. Two years later, the union hired 11 summer interns, all of whom had been active in a campaign against Guess jeans, to work on anti-sweatshop activities. One intern, Tico Almeida, returned to his campus, Duke, and initiated an anti-sweatshop campaign. When Duke agreed to demands that the university insist that its licensees produce items under safe working conditions, with freedom to organize, and independent monitoring, The New York Times carried the story (March 8, 1998, A16). In spring 1998, at a conference in New York, 50 students involved in university-based anti-sweatshop campaigns started USAS . Their major demand was that the Collegiate Licensing Company, the licensing agent for some 160 universities, implement stronger codes of conduct for its suppliers. By 2000, USAS had chapters on nearly 140 campuses, ranging from highly elite universities with a tradition of student protest to small liberal arts schools.

What kinds of students become involved in anti-sweatshop activities? How much time and effort do they give to anti-sweatshop campaigning? What motivates their efforts? To answer these questions we surveyed nearly 100 USAS members in summer $1999 .{ }^{11}$ Forty-two percent of our sample classified themselves as leaders and 31 percent viewed themselves as critical people in their campus anti-sweatshop activities. Nearly three-fourths said they had helped initiate or participate in their local campus campaign. In terms of demographics, the sample is divided nearly evenly between men (53 percent) and women (47 percent) and is dominated by whites ( 84 percent) and non-black minorities (15 percent). Seventy-five percent of the activists are social science majors (some joint majors), usually sociology or political science; 18 percent were humanities majors and the remaining 7 percent were science or mathematics majors.

Panel A of exhibit 5 shows the family background of student activists. Many come from relatively well-to-do families: 36 percent report their family income as exceeding $\$ 100,000$-- more than twice the 16 percent of all first year college students with that family income; while just 8 percent report a family income of less than $\$ 40,000$ compared to 35 percent of first year college students. The parents of activists are more progressive than most Americans, and many parents are themselves activists. As a 
result of this concordance of attitudes, the activist students receive considerable support from their parents. In fact, among parents the proportion who support student activists exceeded the proportion critical of their activity by more than among professors or friends of the students not involved in the antisweatshop movement. These student activists are not Lewis Feuer's generation rebelling against their parents. Rather, they are the product of a generational transmission of political attitudes and activity.

Panel B of exhibit 5 shows that the students have a history of activism. Over half were involved in campaigns in high school, and 84 percent had done activist work prior to their involvement with USAS. Nearly a third had been members of trade unions and 9 percent had been involved in Union Summer. The vast majority viewed themselves as politically committed activists rather than as as apolitical do-gooders. Indicative of their values, the activists said that raising the well-being of third world workers and greater unionization in the United States would make them happier than getting all A's in their classes.

Panel $\mathrm{C}$ shows the time students gave to the anti-sweatshop campaign, to other extra-curricular activities, and to their studies. The activist students spend about 6 hours a week on anti-sweatshop work, with a small number giving over 20 hours a week to the campaign. In addition, the activists spend 13 hours on other extra-curricular activities, so that their total time spent on non-academic pursuits exceeds the time spent studying. Forty per cent hold jobs and work around 11 hours per week. Nearly half say that if they were not involved in the anti-sweatshop movement, they would devote the time to another cause.

The final panel of exhibit 5 shows that students see the main cost of activism as lower grades, but they see little effect on their romantic life, and believe that their activism has increased their selfconfidence, and communication and leadership skills.

Exhibit 6 compares the attitudes of student activists to those of first year college students in the UCLA/ACE annual American Freshman survey on identical questions. ${ }^{12}$ The activists are more "liberal" than freshmen on most issues: they have a more open view toward sex, are less likely to believe that race discrimination is a thing of the past, and are more likely to believe that the wealthy should pay more taxes. At the same time, they are more tolerant of views with which they disagree only 38 percent believe that colleges should prohibit racist or sexist speech compared to 64 percent of all freshmen. The activists are also more favorable to disobeying laws when the laws contravene their convictions and more likely to believe that individual actions can change society. Finally, the activists are markedly less interested in being well off financially or in raising a family than the freshmen and more 
interested in influencing political outcomes and becoming community leaders. In short, their attitudes show that they are indeed "listening to a different drummer" than other college students.

\section{What Activists Produce: Campaigns}

“Look, I don't have time to be some kind of major political activist every time I go to the mall. Just tell me what kind of shoes are okay to buy, okay?" --Teenage girl, St. Mary's Secondary School, Pickering Ontario (Klein 2000, 399)

Human rights vigilantes produce campaigns for labor standards in the global economy. In so doing, they hope to stimulate the concerns reflected in this young woman's statement and help her find

." Their targets are simultaneously consumers like her and the corporations that sell her shoes. The tools they use in their campaigns are the same as those used by other international advocacy networks to pressure targeted actors to change: information politics, symbolic politics, accountability politics, and leverage politics (Keck and Sikkink 1998, 16-25). Most anti-sweatshop campaigns explicitly combine elements of the first three. Over time, the cumulative effect of many campaigns allows activists to leverage their influence with governments and international institutions such as the International Labor Organization (ILO), which have greater resources to act against sweatshop abuses.

The first challenge facing an anti-sweatshop campaign is to obtain accurate, credible information about labor conditions in factories producing brand name goods. Getting such information is difficult, given the long production chains that often link manufacturers or retailers to workers in less developed countries (exhibit 3; Verite). In addition, managers of export processing zones and unsympathetic authoritarian governments often restrict access to facilities, making information-gathering in some cases even more difficult (Klein 1999, 203-04; 212-13).

The second challenge is to package the information in a way that strikes a moral chord among consumers and generates enough publicity to put labor conditions on the public agenda. This is also no easy task. Human rights vigilantes do not have large PR budgets nor automatic access to major media. In a world plagued by catastrophes, wars, and multiple injustices, they compete for attention with other compelling issues as well as with the weekly entertainment, sports, and scandal reports. Often this means that the campaigns need to personalize the message through a spokesperson who becomes the symbol of exploitation or through the closeness between the consumer and the product, as with college 
logo products. The type of abuse highlighted also matters, with child labor and unsafe working conditions attracting more sympathy than restrictions on union activities.

A campaign that succeeds in the first two tasks must then get firms or governments to undertake corrective policies. The typical firm's first response to a campaign is to claim ignorance; then it will announce it has developed a code to prevent such occurrences in the future. In most cases, however, the firm resists independent monitoring of code compliance, which might force it to expend real resources. This is the point where activists turn to accountability politics, using the firm's own promises to pressure them to follow words with deeds. Writing about the corporate responsibility movement in The Nation recently (October 2, 2000), William Greider noted that, "An enduring truth, a wise friend once explained to me, is that important social change nearly always begins in hypocrisy." Thus, antisweat campaigns usually must generate several rounds of publicity and pressure to have any hope of producing a change in behavior.

At this writing, the anti-sweat activists have exposed bad conditions in some factories and elicited promises of reform but have shied away from pointing consumers to shoes and sweatshirts that are "okay." Activists are cautious here for two reasons. First, a campaign that reduces sales will harm the very workers the campaigns are designed to help, so activists generally eschew calls for consumers to boycott products. Second, if activists endorse a given product, and someone finds that somewhere in the world the firm or one of its subcontractors workers is abusing workers (highly likely given the long supply chains), the activists risk losing their credibility.

\section{The 1990s anti-sweatshop campaigns}

Sweatshops have characterized apparel production since industrial revolution days, and so too have campaigns to improve labor conditions in the industry. Many economists point out that low-wage, labor-intensive production of items like apparel is often a taking off point for development in poor agrarian countries with abundant labor and little capital. But low wages alone do not a sweatshop make. Though much debate focuses on wages, there are other practices, such as forced labor or safety conditions or denial of legally-mandated benefits that campaigns also address.

Many of the issues are the same, but a major difference between anti-sweatshop campaigns at the turn of the 21 st century and those at the turn of the 20th century is that sweatshops then were largely local whereas today they are found mostly in poor developing countries. ${ }^{13}$ This means that US-based activists cannot lobby the US government to improve labor standards. Instead, they must target US- 
based corporations who operate or source in developing countries or pressure the world trading community to demand changes in less developed countries. This strategy, as well as many of today's human rights vigilantes, have roots in the anti-apartheid campaign (see box 1). Anti-apartheid activists first pressured firms through the Sullivan Principles and then turned to pressing governments to impose economic sanctions on the apartheid regime. It is perhaps no coincidence that anti-sweatshop campaigns gathered steam in the 1990s after apartheid was formally buried.

Exhibit 7 summarizes the 1990s anti-sweatshop campaigns. They begin in 1992, when Levi Strauss adopted the first known code of conduct addressing sweatshop abuses in response to a Department of Labor investigation into illegal wage and other practices at supplier factories in the US territory of Saipan (Varley 1998, 12). This code included criteria for source country selection, as well as terms of engagement for suppliers. A year later, Levi's announced that it would withdraw from China because the human rights situation was unacceptable; but Levi's never completed the withdrawal and, in April 1998, reversed course and announced it was expanding operations in China.

Shortly after Levi's announced its code, a television broadcast showing children in a Bangladesh factory sewing Wal-Mart label garments led that retailer to develop "Standards for Vendor Partners." But Wal-Mart also soon found itself back in the spotlight. In Spring 1996, the NLC's Kernaghan revealed that clothing endorsed by television personality Kathie Lee Gifford sold at Wal-Mart was made under exploitative conditions in Honduras. Kernaghan had a powerful symbol for this campaign in 15-year old Wendy Diaz, a Honduran orphan who had worked long hours at low wages at the plant since she was 13 to support herself and three younger brothers. Her story struck a particular chord because the Kathie Lee labels advertised her commitment to children and pledged a share of the profits to children's causes. Gifford initially denied the allegations, then condemned the sweatshop practices and pledged to ensure that her clothing line was never again made under such conditions. After other Gifford-endorsed clothing was discovered being manufactured in a New York City sweatshop, Secretary of Labor Robert Reich enlisted her into his "No Sweat" campaign to combat sweatshops in the United States.

Around the same time, activists pressured The Gap to allow independent monitoring by a local NGO of a contract facility in El Salvador. Under similar pressure in 1997, Phillips-Van Heusen (PVH), whose CEO sits on the board of Human Rights Watch, recognized a union at a joint venture facility in Guatemala, a first in that country's apparel export sector (Varley 1998, 141-49). With the sweatshop issue in the headlines, President Clinton joined with Reich, Gifford and others in August 1996 to create 
the Apparel Industry Partnership (AIP) to combat sweatshop practices internationally. Although many multinational corporations and US retailers sourcing abroad had responded to activist pressure and bad publicity by adopting corporate codes of conduct, the codes varied widely in the issues they addressed and did not seriously address issues of compliance. The AIP brought together apparel manufacturers and retailer/importers, unions, and NGOs in an effort to develop an industry-wide code and a credible monitoring mechanism to verify compliance.

When the AIP released its draft code and principles for monitoring in April 1997, antisweatshop activists had divergent views on its value. Global Exchange's Medea Benjamin blasted it as a "lousy agreement," primarily because it did not include a living wage, while UNITE President Jay Mazur, an AIP member, called the code "unprecedented" and "a step in the right direction" (NewsHour transcript, April 14, 1997). Continuing negotiations on implementation quickly bogged down, however. In November 1998, the AIP unveiled plans to create a Fair Labor Association to oversee implementation and monitoring of the code. UNITE, and the other union member, the Retail, Wholesale and Department Store Union, and the Interfaith Center for Corporate Responsibility rejected the FLA as too weak and left the organization. These groups complained that the code failed to require payment of a living wage; had weak language with respect to union rights in nondemocratic countries; and had a weak monitoring and verification mechanism.

Nearly two years later, the FLA still had no union representatives and had filled only five of the six board seats allocated for labor, human rights, and consumer groups. To maintain the balance required by the FLA's charter, only 5 corporate representatives sat on the board and, overall, corporate membership had increased only to 12 from the original 9, including Kathie Lee Gifford, Nike, Reebok, Philips-Van Heusen, and Levi's (www.fairlabor.org, last visited October 11, 2000). More than 140 universities affiliated with the FLA, but this led to more troubles for the organization.

Activist university students began coalescing around the anti-sweatshop issue in 1997 and formed an organization, the United Students Against Sweatships (USAS) shortly after to pressure their schools to require codes of conduct for all licensees producing college-logo apparel. Student activists condemned the universities for joining what they viewed as the ineffective FLA and created the Worker Rights Consortium (WRC), with a stronger code and alternative "verification model" (exhibit 8). USAS pressured universities to join the WRC instead of the FLA. By June 2000, more than 50 universities had signed on, though some, such as Brown University and the University of Michigan, affiliated with the FLA as well. 
In a separate effort, the Council on Economic Priorities (CEP), which has for many years provided information on the social and environmental policies of companies, developed SA 8000 in consultation with corporations, unions, and NGOs, including representatives from developing countries. The CEP also established an agency, recently renamed Social Accountability International (previously known as CEPAA) to accredit auditors of the SA 8000 standard. As of end-2000, SAI had accredited 5 auditors who had in turn certified some 60 manufacturers or business service organizations, more than half in China, as in compliance with SA 8000. At least one of the plants in China was decertified, however, after an NLC report alleging a variety of violations was confirmed by SAI auditors (Business Week, October 2, 2000). The organization also has 7 retailer "members," including Avon, Toys R Us, and Dole Foods; who are expected to encourage their suppliers to seek certification.

Another organization, Verite, established in 1995, provides firms with independent monitoring of working conditions through human rights inspections of factories worldwide, particularly in China and Asia. Though hired by firms, Verite retains the right to publish the results of its inspections if the firm does not rectify problems in six months (Rothstein 1996). The Ethical Trade Initiative is a European effort that combines elements of the FLA and CEPAA, though it does not plan to create its own monitoring mechanism. Rugmark is another European initiative that a US group has replicated here, to label hand-made carpets as child-labor free. ${ }^{14}$

Arguments over codes of conduct among activists and between them and firms have highlighted three key issues in using workplace codes to improve labor conditions: what goes into the code, the disclosure of plants covered by the code, and who monitors the code (exhibit 8). The most divisive issue regarding the content of codes is whether to include a living wage: SA 8000 and the WRC do, the FLA does not. The idea of a living wage resonates with many people, but it is difficult to define and many corporations oppose it, which could deter broad acceptance of codes that include this provision. The WRC has said that, while a living wage is crucial to their code, universities are not required to implement that provision pending research on how to measure it. A second area of disagreement has been over how to ensure freedom of association in countries such as China where the state restricts this right.

Regardless of content, codes can gain broad public support only if they have a credible monitoring mechanism. For outside NGOs or any other independent organization to monitor adherence to codes, there must be transparency in the names and locations of subcontractors. Initially major manufacturers refused to identify their subcontractors, claiming it was a trade secret. The failure of the 
FLA to require such disclosure contributed to the decision by USAS to develop the Worker Rights Consortium as an alternative. The students' persistence on the disclosure issue was rewarded in fall 1999 when several firms agreed to make this information public, including Nike, which released a list of 41 plants producing licensed apparel for Duke, North Carolina, Georgetown, Michigan, and Arizona (www.nikebiz.com/labor/disclosure.shtml; last visited January 1, 2001).

Equally divisive is the issue of who does the monitoring. Firms prefer monitors from the business community, such as PricewaterhouseCoopers (PwC) and Ernst andYoung, whom they pay and with whom they often do other business. Activists prefer monitors from local NGOs because they believe workers will feel more comfortable talking to them and, therefore, more likely to be honest in discussing problems at the plant. They are suspicious of business monitors and are fearful of Potemkin Village audits of the kind that Andrew Young performed for NIKE in 1997 with a whirlwind tour of factories that concluded all was well. Such skepticism appeared justified when the Transnational Resource and Action Center posted on its Corporate Watch website (www. corpwatch.org) a leaked Ernst and Young audit that concluded that Nike violated a number of Vietnamese labor laws. A recent report by O'Rourke (2000) identified a number of problems with company-arranged audits by $\mathrm{PwC}$, especially in the areas of freedom of association and health and safety. O'Rourke concluded that PwC's methodology was flawed, biased toward management, and that the auditors themselves were inadequately trained.

The FLA and CEPAA address these problems by requiring that companies use an auditor that has been certified by them as qualified to do independent verification of compliance. Both organizations require monitors to consult with local NGOs and encourage NGOs to apply for accreditation but critics argue that the accreditation procedures are too expensive or too complex for most NGOs to master. In an interesting variation, the FLA allows agents to be accredited to monitor particular parts of the code, without being expert in all of them. Although the FLA does not explicitly encourage member companies to use teams of monitors, with expertise in different areas, this provision at least envisions such a possibility.

But USAS objects to the fact that the traditional accounting firms can be certified under these programs and believes that the FLA approach leaves too much control in the hands of the corporations (see exhibit 8). Realizing that even the best monitoring system cannot certify with 100 percent certainty that even one factory is in compliance with a code 365 days a year, the WRC rejects the typical monitoring and certification model because it conveys a "good housekeeping seal of approval," even 
when problems remain in some areas. Their verification model enforces compliance through complete disclosure of plant locations and information on conditions in them, backed by a system of local NGOs prepared to receive worker complaints.

Indicative of the depth of these conflicts, in spring 2000 NIKE ended licensing agreements with Brown and the University of Michigan and cut off personal and corporate contributions to CEO Phil Knight's alma mater, the University of Oregon, after these universities joined the WRC. Nike objected to the unwillingness of USAS to include corporations in the negotiation of WRC principles and procedures and also criticized the "ambiguous living wage" provision and "gotcha monitoring" (www.nikebiz.com/media/n_uofo.shtml; last visited September 1, 2000).

\section{Assessing the effectiveness of the campaigns}

In their analysis of transnational advocacy, Keck and Sikkink $(1998,25)$ identify five levels of potential effectiveness:

- "issue creation and agenda-setting,"

- "influence on discursive positions of states and international organizations"

- "influence on institutional procedures"

- “influence on policy change in "target actors"” (states, international organizations, corporations or other private sector actors)

- "influence on state [or corporate] behavior."

Examining selected anti-sweatshop campaigns from this perspective shows that activists have succeeded in getting the sweatshop issue on the agenda of corporations, governments and international organizations; and have influenced the discursive position of states and international organizations, and firms as well. Most major visible retail marketers have adopted corporate codes of conducts addressing various labor standards. ${ }^{15}$

But the effects on behavior are weaker. Exhibit 9 provides a summary of various campaigns together with a crude measure of their achievements, using a 1 (little or no effect) to 5 (very effective) scale. We have given low scores even to relatively successful campaigns in part because some targeted firms backed off from their early responses or were subsequently found to have done less than they promised. For instance, Kernaghans's revelations about Kathie Lee apparel raised questions about Wal-Mart's earlier commitment to enforcing its code of conduct. Subsequent allegations about WalMart contractors in China, Saipan, and elsewhere suggest changes in behavior remain elusive. Phillips- 
Van Heusen canceled its contract with the unionized plant in Guatemala, forcing its closure. PVH claimed it did so because it lost a major contract and had excess capacity, but critics questioned the significance of the business lost and wondered why PVH could not have reduced capacity at a nonunionized plant. Independent monitoring at The Gap facility in El Salvador continues and Liz Claiborne, a member of the FLA, also signed an agreement for independent monitoring of a supplier there. Levi Strauss expanded its operations in China despite a worsening human rights environment and initially resisted joining the FLA or allowing any external monitoring at its facilities. In 1998, however, Levi's approached Oxfam about establishing a pilot monitoring program in its Dominican Republic operations and subsequently joined both the FLA and the Ethical Trade Initiative in Europe (Oxfam 1998-99).

In contrast to these partial or sometimes temporary successes is the failed NLC campaign against Disney and its licensees in Haiti. With its focus on children and family values, Disney looked like a good follow-on to the Kathie Lee campaign. Instead, Disney was perhaps the NLC's biggest failure. Although Disney sent its own investigators to check out the facilities in Haiti and reportedly pressured them to make some improvements (see www.cleanclothes.org), one Disney subcontractor in Haiti withdrew, causing the shutdown of the plant. Disney alternated between flatly denying the allegations or simply not responding. Although Kernaghan staged protests outside a Disney store in New York, consumers did not respond and the pressure did not force any substantial change in Disney's operations (Los Angeles Times, July 25, 1996). One possible reason this campaign failed is that children are the ultimate consumer and many parents cannot say no when their child desperately wants the latest Disney product that all their friends have. Another possible explanation is that it was difficult to embarrass Disney CEO Michael Eisner as a hypocrite because he lacks visible links to human rights and charitable causes that other targets have had. ${ }^{16}$

The narrow membership of the FLA and SAI; the difficulties in getting the FLA monitoring system up and going; the split between the FLA and Worker Rights Consortium, and the development of SA 8000 in competition with both highlight two weaknesses of the anti-sweatshop campaigns. The limited membership of the umbrella groups, combined with Nike's reaction to the WRC and Disney's stonewalling of Kernaghan, suggest that most firms still view the activists as a minor rather than serious threat. The proliferating number of groups risk consumer confusion and frustration, which could further exacerbate the problem of generating enough demand to force changes in corporate behavior (Freeman, 1998; Liubicic 1998). ${ }^{17}$ 
Could these divisions be reduced and the various participants in the anti-sweatshop activity advance under a common banner? The example of environmental groups interested in promoting sustainable forestry suggests that under some circumstances different activists and firms can coalesce around a common standard overseen by a single accreditation agency. In 1993 environmental groups, forest companies and retailers, negotiated a code and developed the Forest Stewardship Council (FSC) for certifying compliance (see box 2). Some environmentalists have criticized the FSC for cooperating too closely with industry groups, but large American timber companies formed the rival Sustainable Forestry Initiative because they regard FSC standards as too stringent. Nevertheless, the FSC has succeeded in getting commitments from major retailers selling more than 20 percent of the lumber products used in home repair and remodeling in the United States and an even higher share in Europe. "Industry executives say the movement is quickly reaching critical mass, and could soon make it a liability for wood products producers not to have the FSC imprimatur"' (Wall Street Journal, September 26, 2000, 1)

However, there are important differences between consumer desire for clothing made outside of sweatshops and the desire for sustainable forestry. Self-interest among firms operated as an important motivator in sustaining the FSC campaign, in ways that it has not in the anti-sweatshop area . Several wood products retailers identified a competitive advantage in being "green" and thus were willing to make commitments to buy FSC-certified products. ${ }^{18}$ Individual consumers also often see gains to themselves from environmental improvements, whereas the beneficiaries from improvements in sweatshops are the workers in those factories. The sustainable forestry campaign also suggests that vigilante pressure works better when there are a relatively small fixed number of market leaders whose actions can be readily monitored. Sweatshop activists have focused on major firms, but the wide supply chain in apparel makes it hard to pin down key decision-makers. Moreover, in both forestry and apparel, a successful campaign can disadvantage small suppliers. In the forestry case, this presumably creates no new environmental problem, but in the sweatshop case, success may displace home-workers or others in the informal sector who cannot enter the formal economy for cultural, child-rearing or other reasons. ${ }^{19}$

The anti-sweatshop activists also have a more difficult task than anti-apartheid activists in an earlier era. In contrast to ending apartheid, success in eradicating sweatshop exploitation is more difficult to measure: exactly what defines a sweatshop and what does it mean to clean them up? Success is measured in incremental steps and requires constant vigilance to guard against backsliding. 
The anti-apartheid activists had strong union and non-governmental groups in less developed countries with which to work, and the ANC to press for changes on the ground. Indeed, in contrast to the antisweatshop activists, who are leading the worldwide campaign against sweatshops, anti-apartheid activists played a more secondary role, supporting the ANC in its efforts to overturn the minority apartheid regime in South Africa.

\section{Risks and Limitations of the Activist Consumer-based Model}

Most developing country governments, multinational corporations, and trade economists, and many development experts argue that anti-sweatshop campaigns are likely to do more harm than good. $^{20}$ How valid are their concerns? How much good can even the most successful activist-initiated, consumer-based campaign do in improving labor standards in poor countries?

\section{The risk that doing good will do harm}

"Bad jobs at bad wages are better than no jobs at all." Paul Krugman ${ }^{21}$

"Empleo si, pero con dignidad." Nicaraguan Maria Elena Cuadra, Movement of Working and Unemployed Women. ${ }^{22}$

The argument that anti-sweatshop campaigns risk harm to workers in less developed countries begins with the fact that sweatshop jobs are better than jobs in rural agriculture or the informal sector, particularly for the young women who make up the bulk of the sweatshop work force. Studies of wages and employment show that foreign-owned and export-oriented factories in developing countries offer higher pay and better conditions on average than those of domestic firms producing for the local market (Varley 1998). Wages in footwear and apparel may be at the bottom of manufacturing, but they are generally higher than the minimum wage level in many developing countries and better than conditions in agriculture (US Department of Labor 2000). While there are situations where workers are mislead by employer promises, subject to forced labor, or paid less than they are promised, workers choose sweatshop jobs because those jobs are the best alternatives available to them.

Critics of human rights vigilantes fear that the campaigns will discourage exports from less developed countries and reduce foreign investment in those countries, which would lower the demand for labor and reduce worker well-being. Some believe that the activists are motivated by protectionism

or are misguided followers of those who are. The evidence in earlier sections rejects this assertion. The 
human rights groups, students, and church groups who make up the activist community do not compete with low paid workers in developing countries. If they succeed in their campaigns, they will raise the prices of the goods they consume rather than raise trade barriers. USAS, which has close ties to the apparel union UNITE, has opposed firms shifting production of college logo clothing to US factories as a means of improving standards (Moore 2000, 10). The NLC's Kernaghan has also criticized firms that "cut and run" rather than clean up and monitor a substandard facility.

But motivation aside, anti-sweat campaigns could still have adverse effects on developing country workers. Even if anti-sweatshop campaigns do not call for consumer boycotts of targeted goods, negative publicity could deter trade and investment and reduce the number of jobs available in countries with already high levels of unemployment and underemployment. Or campaigns could have the perverse effect of pushing production out of the formal sector into areas of the economy with even lower standards and less visibility. Demands for living wages in anti-sweatshop campaigns run the greatest risk of backfiring, since such demands could price workers in less developed countries out of some markets. This is particularly the case if the living wage target is determined by outside activists with strong ideological stances rather than by local NGOs or unions who can better weigh the danger to jobs of large imposed increases in wages. In terms of our analysis, an "excessive living wage" would place the cost curve for making improvements far above the price line, so that firms would fight this demand, or close shop.

To date, however, the danger that anti-sweat shop campaigns will harm workers in less developed countries has been more rhetoric than reality. One reason is that the activists are aware of the dangers and try to avoid them. Indeed, the wide range of groups in the activist community almost guarantees that if some group pushes demands that are counter-productive another group will modify them or take corrective action.

Campaigns against child labor provide an example of this. The ILO's International Program on the Elimination of Child Labour works to replace child labor with better opportunities. In two cases, involving the Bangladesh garment industry and Pakistani-produced soccer balls, external pressure led to joint initiatives involving industry, government, and the ILO that required the provision of educational alternatives for displaced child workers and turned a potential harm into a positive outcome. In Bangladesh, more than 12,000 children were moved from work to school and their share of the workforce in the garment sector has fallen from an estimated 30 percent to just 5 percent five years later (ILO 2000, 55). In Pakistan, thousands more children also have better opportunities as a result of 
outside intervention and assistance. Similarly, consumers buying Rugmark-labeled, child-free carpets pay a premium that, in addition to paying the costs of certification, goes to build schools for affected children. In the absence of ready alternatives, NLC campaigns that target child labor concentrate on increasing the pay for children, rather than on getting firms to produce goods child-free.

Activist debates over living wages also give considerable attention to the dangers of unintended adverse consequences. A 1999 anti-sweatshop symposium at the University of Wisconsin warned that campaigns "may produce serious negative feedback loops. These could include the following: Firms may concentrate their production of college apparel in high-wage countries, moving more of their other operations to the lower-wage economies. ... Firms could maintain production in the low-wage economies, but create small high-wage enclaves within them (which would have) little positive effect on the rest of the local labor market. Setting the wage too high relative to local market conditions could create difficulties for monitoring. This is because a strong incentive would be created to circumvent the wage mandate. For example, workers could sell a share of their high-wage jobs under the table to their relatives or friends; so that, in fact, multiple workers are employed at a single 'living wage' job." The conclusion was that any campaign had to take account of local market conditions and base its decision on "What would be the wage bargained for by workers if they were allowed to organize and bargain collectively in a free, democratic environment?"23

Fears that anti-sweatshop campaigns could reduce foreign investment and jobs in less advanced countries seem in any case beside the point in a world where the overwhelming trend is toward expansion of manufacturing, particularly apparel and shoes, into less developed countries. The income gaps between those countries and advanced countries are so great that it is difficult to imagine a scenario where anti-sweatshop activism could reverse this trend, even if, contrary to the evidence, the activists wanted to accomplish as much. The danger is much more that firms will shift their operations from less developed countries with higher and more expensive standards to similar countries with lower and less expensive labor standards. As an example, in the banana industry, lower-cost labor in Ecuador --in part the result of low unionization rates -- threatens workers in Colombia. But such threats are likely with or without activist campaigns.

\section{Limits of the market for standards}

Assume that human rights vigilantes ran a completely successful anti-sweatshop campaign, inducing all their targets to have verifiable codes of conduct and avoiding adverse unintended 
consequences. By itself, how much would this raise living standards in the targeted countries? Sadly, not by much. Consumers appear to care largely about the ways in which the things they personally consume are produced, so that virtually all campaigns focus on standards in export sectors in less developed countries, rather than in sectors with the worst labor conditions or on conditions in less developed countries more broadly. ${ }^{24}$ In total, exports by low income countries of apparel and footwear are only 2 percent of world exports, 14 percent of total low-income country exports, and 3 percent of their GDP.

Moreover, since the major stick behind the campaigns is the threat to corporate reputations or brand names, activist campaigns target well-known firms, rather than producers of generic and unbranded products, who may produce goods under poorer conditions than better-known firms. The high-end retailer/marketer who uses a relatively smaller number of more stable suppliers is also more likely to be able to enforce compliance with standards. Lower-end retailers, such as Wal-Mart,who are more interested in price than quality or design often use middle-man buyers to locate suppliers, making it hard to enforce their codes of conduct. The college apparel market targeted by USAS is smaller yet.

In short, human rights vigilantes cannot greatly improve living standards in poor countries under any realistic scenario -- only sustained economic growth can do that -- though they may be able to bring some modest gain in well-being to some workers.

\section{What about the workers?}

"In the end the only ones who can stand up for workers' rights are workers themselves" Medea $\operatorname{Benjamin}^{25}$

Anti-sweatshop campaigns in advanced countries would be unnecessary if workers in less developed countries were free to defend their own well-being by forming trade unions or other such organizations. At best activists in advanced countries interceding for workers is a second best alternative to workers defending their own rights, negotiating with management appropriate standards, and jointly monitoring implementation. In industries with high labor turnover, external monitors cannot readily inform workers about codes of conduct, nor provide the day-to-day scrutiny of facilities that workers can (Frost 2000; Bernard 1997).

More broadly, Keck and Sikkink (1998) found that having allies within the targeted country was a factor in many of the successful cases of transnational advocacy that they studied. Vocal support 
for economic sanctions by black leaders in South Africa, even though they were the ones expected to suffer the most economic pain, was an important factor in the success of the anti-apartheid campaign.

In contrast, anti-sweatshop campaigns have made little or no headway in pressing for freedom of association in less advanced countries, which would give exploitated workers a voice. The WRC, the FLA and SA 8000 codes include respect for freedom of association and collective bargaining rights, but implementation of these codes is difficult absent major changes in the developing countries themselves. Even corporations concerned with standards typically leave union rights out of their codes of conduct (ILO 1998; Varley 1998) Business is anti-union because unions will alter authority relations within firms and shift revenues from owners to workers (ILO 2000, 61-63). The government of many less developed countries, including China, oppose independent unions, because unions are an independent source of power on a political scene otherwise dominated by a single party or narrow elite. These attitudes make unionization extraordinarily difficult to attain, even in countries that nominally accept the freedom of association standard of the ILO. At the same time, activists are likely to have trouble arousing consumer concern over the freedom to unionize, according to the PIPA poll in exhibit 1.

Campaigns where unionism was a key issue, as with the PVH plant in Guatemala, have not been sustained for long. By shifting orders to a nonunion firm, multinationals can readily undo the effects of successful organization, or they can accede to other demands but not to demands for organization. At the Gap's Mandarin factory in El Salvador, the main source of contention was the unwillingness of management to allow formation of a union and the firing of union organizers. After the campaign publicized violations in the company's code of conduct, the Gap worked to improve conditions and even guaranteed a minimum number of orders, offsetting lost orders from elsewhere that resulted from negative publicity (Varley 1998, 302). In addition, the Gap allowed independent monitoring, but there is still no union in that plant.

In fact, although some human rights vigilante groups, like the NLC and USAS, have close ties to trade unions, there are serious tensions between the vigilante groups and unions (Compa, 2000). The anti-sweat NGOs are not elected by workers. They are accountable to consumers, funders, and other Western supporters. Some trade unionists fear that the vigilantes demands for corporate codes of conduct and independent monitoring will inadvertently serve as a weak substitute for unions. On the other side, the NGOs feel that they can accomplish something, while it is unrealistic to expect free and independent unions to operate in many third world countries. 
In a September 1998 workshop organized by the British-based NGO Labour Rights Network (the NGO representatives to the Ethical Trade Initiative), representatives from developing countries stressed the importance of involving local NGOs and unions from the beginning in anti-sweatshop campaigns to ensure that they address local priorities and interests. They agreed that while "Codes could be useful as a means of exerting leverage on management, the key issue was workers' own level of organisation and ability to carry out collective bargaining. ... The ideal combination is for NGOs to play a supporting role by providing training and services and campaigning for the respect of trade union rights, and encouraging more traditional unions to take up previously unrepresented groups and gender

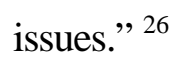

Of the other human rights vigilante groups, USAS has been particularly attuned to the need to gain support from workers groups on the ground. The Workers Rights Consortium eschews the usual monitoring agencies and emphasizes the need to engage and strengthen local workers' organizations and NGOs by providing financial and technical assistance.

\section{Conclusion: When Does Doing Good Do Good?}

"Not to sound Pollyannish, but I believe there is a basic decency in the American people that these companies don't understand. We have to try to tap this decency. When we do that, we get a The New York Times, June 18, 1996)

The goal of anti-sweatshop campaigns is to improve conditions for workers in less developed countries. But they cannot do this directly. Their effectiveness depends on catalyzing other economic agents: firms, governments, international agencies, and the sweatshop workers themselves. To what extent and under what conditions have campaigns succeeded?

A priori, there are a range of possible outcomes from anti-sweatshop campaigns: (1) the campaigns could make things worse by generating negative publicity that causes sales or prices to drop for the products of sweatshop workers; (2) the campaigns could have no effect at all if firms do not view the threat of a consumer backlash as credible; (3) the campaigns could catalyze firms to improve standards when the consumer threat is credible relative to the cost of improvements; or (4) the campaigns could catalyze firms, governments, and international agencies to undertake broader sustainable improvements. 
Our analysis rejects (1) and (2) but indicates that the activitists have had some limited success in catalyzing consumers and firms to change their behavior to improve sweatshop conditions. Activist campaigns have succeeded in getting most major, visible retailers and marketers to develop their own corporate codes of conduct addressing various labor standards. They have induced some, such as the GAP and NIKE, to improve labor conditions in their overseas factories, at some expense. The April 2000 Starbucks agreement to market Fair Trade certified coffee, which gives farmers a premium over the prevailing market price, would never have been done had not human rights vigilantes developed a social climate where such actions are seen as in the corporate interest. Similarly, the fact that Nike and Reebok eliminated toxic chemicals in the production of athletic footwear is, at least in part, a response to activist pressures. And while many activists attack the FLA because it is much weaker than they would like, its creation, and that of SA8000, are also a product of their campaigns. Some campaigns have indeed shifted the price curve facing firms so that the firms have chosen the "improved standards" solution (see exhibit 4). So far, however, the successes are ad hoc and often temporary.

The limited direct effects of campaigns are not the end of the story, however. The antisweatshop activists have had gotten sweatshop issues on the international agenda and, together with unions and other groups protesting the policies of the World Trade Organization (WTO), have convinced key governments and international agencies that they must deal with labor standards to maintain support for liberal trade policies. This pressure has contributed to a variety of efforts by agents with more reach and power than the activists to empower workers and better enforce labor standards.

On the government side, the insistence of the Clinton administration that new multilateral trade negotiations address labor standards issues is a response to activist and US union pressures. Without these pressures, new "fast-track" trade negotiating authority likely would have been approved by Congress without attention to this issue (Elliott 2000). Congress also would not have raised the US contribution to the ILO campaign to eliminate child labor from \$2.1 million in 1995 to $\$ 45$ million in 2001 (Congressional Record, December 15, 2000, H12128). While the US cannot dictate the place of labor standards in the next round of world trade negotiations -- China and other less advanced countries are adamantly opposed-- the fact that the debate is not whether but how to strengthen enforcement of core labor standards (as defined by the ILO, World Social Summit, and others) is an important outcome from a decade of activism.

On the international agency front, activists have put labor rights on the world agenda in a big way. In 1999, UN Secretary General Kofi Annan unveiled a new "Global Compact," calling on the 
business community to respect nine core principles in the areas of human rights, worker rights, and environmental protection. The Organization for Economic Cooperation and Development recently added language on worker rights to its guidelines for multinational corporations and The World Bank has a child labor program and is focusing more attention on gender discrimination issues. Maybe with a bit more pressure, the International Monetary Fund will endorse transparency in labor markets, as it does in capital markets and the World Bank will drop its ambivalence about the role of unions in development.

The major beneficiary of activist pressures to strengthen enforcement of standards is the International Labor Organization. As a result of the desire of employers and key governments to divert pressures to incorporate labor standards in the WTO and other trade agreements, the ILO is receiving both more attention and more resources to deal with "core" labor standards, especially child labor. Yes, the 2000-2001 \$56 million budget for the ILO’s Program to Eliminate Child Poverty is minuscule in comparison with the revenues and expenditures of almost any multinational firm. The ILO also does not have anything like the financial resources to push its child labor program that the IMF or World Bank have to push their programs of financial reforms or economic rectitude. But this is a huge increase over previous budgets, with much of the increase funded by the United States. In addition, the ILO codified the consensus definition of "core" labor standards in its 1998 "Declaration on Fundamental Principles and Rights at Work" and is also receiving increased funding from the US and other governments to beef up the monitoring of and technical assistance for the enforcement of core standards.

The best example of how activism has galvanized the ILO and produced a better outcome for workers than activists could have attained by themselves is in the child labor area. In the mid-1990s, activists exposed the use of child labor in the Bangladeshi garment industry and in the soccer ball industry in Pakistan and pressured retailers to address the problem. The initial industry response in Bangladesh was to throw the children out on the street and it was only after the ILO and UNICEF intervened that a constructive solution was found. Manufacturers in Bangladesh and Pakistan agreed not simply to stop employing children but to cooperate with and assist in the funding of programs to put them in schools or other rehabilitative training, and to allow the ILO to monitor the results.

Finally, the upsurge of labor activism in some poor Asian countries, notably Cambodia and Indonesia, shows how external pressure and support, in these cases from activists, governments, and the ILO, can empower workers (Time, July 10, 2000, “Hell No, We Won't Sew”). In a bilateral trade 
negotiation with Cambodia, the United States responded to activist and union pressure to promote labor standards by using its market power as a carrot, rather than a stick. As part of a bilateral textile trade agreement, US negotiators offered to expand Cambodia's export quota by 14 percent if "working conditions in the Cambodia textile and apparel sector substantially comply with [local] labor law and standards." ${ }^{27}$ In the first review in December 1999, US officials concluded that "substantial compliance" had not been achieved but, in recognition of the progress that had been made, it offered a 5 percent quota increase to be implemented when Cambodia completed an agreement with the International Labor Organization (ILO) creating an independent monitoring program (USTR press release, 18 May 2000). The ILO agreed to the plan after gaining a commitment from US officials to fund a parallel program to provide technical assistance and training to the Cambodian labor ministry and the quota increase was granted in May 2000. In response to worker protests following conclusion of the bilateral agreement, the secretary-general of the Cambodia Garment Manufacturers Association complained, "All the attention gives the workers the comfort level that they are calling the shots" (Financial Times, April 7, 2000). In this case, activist pressure contributed to empowerment of the 15 to 20 percent of Cambodian workers in the apparel sector, at least some increased access to the US market, and increased bureaucratic capacity to enforce labor standards for all workers.

Despite signs of movement, activists have been least successful is in moving the core labor standard of freedom of association and the right to collective bargaining from rhetoric to reality. These "enabling rights" would allow sweatshop workers to decide for themselves what issues to pursue, trade-offs to make, and battles to conduct with their employers and would probably do more for improving labor standards than anything else. The activists are a key voice directing attention to violations of the rights of workers who seek to exercise their rights overseas, but they ultimately must rely on workers and institutions in those countries to take the lead, much as the African National Congress and COSATU did in South Africa. ${ }^{28}$

Still, these cases show that activist pressure can catalyze more powerful actors on the world scene and contribute to improvements in whole sectors, rather than single plants. Such agreements are likely to be more sustainable than standard anti-sweatshop campaigns because the ILO and Western governments provide financial and technical assistance and because the ILO monitors implementation.

Finally, while anti-sweatshop campaigns do risk reducing the flow of resources to less developed countries, they can also increase those flows. At the consumer level, this can occur when consumers pay for improvements in labor standards through higher prices or when the campaigns 
squeeze oligopolistic profits on branded goods. In some sectors, such as soccer balls which are overwhelmingly sourced in Pakistan, or in cases where campaigns cover the bulk of firms in a sector, they have the potential to improve the terms of trade for the less developed country (Brown, Deardorff, and Stern 1993). At the national or international level this can occur through an increase in expenditures in technical assistance or funding of programs, for instance to move children from work to school. But to have a bigger effect, the anti-sweat activists would have to tackle issues that go beyond poor labor conditions in particular factories or in particular products - such as debt relief and reduction of trade barriers to developing countries -- that they have thus far not put at the front of their agenda.

In sum, by putting labor rights and the living standards of workers in poor countries on the agenda of powerful economic agents and governments and international agencies, human rights vigilantess have catalyzed something that has the potential for improving the well-being of workers in poorer countries. There is nothing in economic analysis, however, that guarantees a positive result nor that guarantees the bad outcomes that critics of the activists fear. It depends on the smarts of the activists and their campaigns. 


\section{Box 1 Precedents in the anti-apartheid campaign}

An early attempt to use grass-roots pressure to influence corporate policies in foreign countries was the anti-apartheid campaign of the 1970s and 1980s. ${ }^{29}$ Seeking to put pressure on the minority white South African government to reform, anti-apartheid activists first tried to convince foreign investors to withdraw from South Africa. When that failed, the Reverend Leon Sullivan developed a code of conduct to encourage corporations in South Africa to treat black workers equally and to set an example by promoting them to management positions. To induce companies to either withdraw from South Africa or accept the Sullivan Principles, activists used threats of boycotts, shareholder pressure by church organizations, and protests by college students calling on their universities to cleanse their endowments of investments in companies operating in South Africa. The Sullivan Principles were ultimately adopted by hundreds of companies and resulted in improved working conditions in affected facilities. But the ultimate goal of the activists remained the end of apartheid in South Africa and the Principles had little impact on the white regime's commitment to or ability to sustain apartheid.

As unrest and violence escalated in the mid-1980s, increasing numbers of foreign investors withdrew from South Africa, but this was due more to the deteriorating economic and political situation in South Africa than to pressure from anti-apartheid activists. In particular, the decision by Chase Manhattan not to rollover loans to South Africa in mid-1985, following the government's declaration of a state of emergency, appears to have been driven by an assessment of the risks involved in investing in South Africa rather than activist pressures in the United States. That decision in turn triggered a financial crisis in South Africa.

Frustrated by the intransigence of the white regime, American activists turned their attention to the US Congress. Civil disobedience by protestors over the course of many months in front of the South African embassy in Washington raised the profile of the issue and contributed to passage of legislation imposing economic sanctions against South Africa in 1986. In 1987, Sullivan gave up on his code and called for additional sanctions, including mandatory corporate withdrawal from South Africa. Although economic sanctions did not cause the financial crisis, public pressure and sanctions complicated its resolution and contributed to the realization in South Africa that fundamental political reforms would be needed to achieve sustainable growth (Hufbauer, Schott, and Elliott, forthcoming). After more than two decades of sustained activism with limited success, the financial crisis coupled with 
the end of the Cold War contributed to rapidly accelerating reforms and the fall of the white minority regime in 1994.

Besides providing precedent and people, the anti-apartheid story contains potential lessons for the anti-sweatshop activists. First, it underscores the fact that corporations typically respond only to external pressures that tangibly affect their bottom line. Most multinationals in South Africa were willing to adopt the Sullivan Principles because it was a relatively inexpensive way to protect their reputation while maintaining profitable operations. The accelerated pace of withdrawal in the mid-1980s was largely due either to conditions in South Africa that increased risk or reduced profitability, such as the financial crisis, or to government actions that had similar effects, such as the denial of credits for taxes paid in South Africa.

Second, perhaps the most important roles that the anti-apartheid activists played were in terms of symbolic and leverage politics. Anti-apartheid activists within South Africa supported and gained politically from the imposition of sanctions. The support of external activists bolstered the ANC and their allies psychologically and, when the white regime finally came to the table, sanctions gave the ANC leverage in negotiating the terms of the transition. In addition, by influencing the American and Commonwealth governments, the activists contributed to the sense of isolation and growing hopelessness about the future among whites in South Africa. 
Box 2 Environmental labeling and the Forest Stewardship Council

The FSC is an independent nonprofit NGO that accredits certifying organizations who, in turn, monitor member companies and certify forest products as being in compliance with the FSC's code of ten principles for sustainable forestry. It was founded in October 1993 when the World Wildlife Fund joined with the Rainforest Alliance (a New York-based NGO with its own certification scheme) and representatives of forest companies and retailers, including B\&Q (Britain's largest home improvement retail chain), to negotiate a code and procedures for certifying compliance. ${ }^{30}$ The organization is transparent and democratic, with a governing body composed of three separate "chambers" with representatives of social, environmental, and economic interests. Although more radical environmental groups criticized the FSC for having corporations as members, several of the most prominent environmental activist groups joined, including Greenpeace International, the Sierra Club, and various chapters of Friends of the Earth. With their support and that of a few large retailers, FSC quickly became the market leader in forest product certification. It created a standard code, established credibility through independent monitoring, and provided consumers with readily available information by creating an easily recognized logo to mark certified products. ${ }^{31}$

In its first seven years, the FSC accredited nine "certification bodies" in six countries, has seven applications pending, and has certified nearly 20 million hectares in 33 countries, including 1.8 million in the United States. To keep up the pressure on the demand side, NGOs convinced Ikea, the world's largest furniture retailer with 1999 sales of \$8.5 billion, and Home Depot, the largest do-it-yourself company with 1997 sales of $\$ 24$ billion, to phase-out wood products from old-growth forests that have not been certified. ${ }^{32}$ In 1998, under pressure from its customers, the largest forestry company in British Columbia, MacMillan Bloedel, announced that it would no longer clear-cut old-growth forests in coastal BC. The following spring, two other BC forestry companies followed suit (Hoberg 1999). In addition, there are a number of national initiatives to form "forest and trade networks," which have evolved from "buyers' clubs" with the aim of "span[ning] the industry from forest owner to architect, manufacturer to retailer," to promote FSC certification (www.panda.org/tradefair2000/ network.htm; last visited June 9, 2000). As of June 2000, there were networks in North America, Australia, the Nordic countries and eight other European countries involving more than 500 member companies.

The FSC example shows that activist-inspired, consumer-based campaigns can contribute to changes in market behavior, but it also underscores the limitations to such campaigns. First, as the 
WWF concedes, the area of certified forest is "modest" and the supply of certified products is "limited." The 20 million certified hectares compares to an average 11.3 million hectares lost each year to deforestation out of a total 3.5 billion hectares of global forest cover. Only around 3 million hectares are certified in tropical forests areas of the developing world, where deforestation is of the most concern. ${ }^{33}$ Second, the market impact of certification is difficult to assess because there are no data on the volume or share of wood products from certified forests. Third, FSC credibility depends on the ability to verify the chain of custody, which is most easily done when there are relatively small numbers of large buyers and sellers. Small forest owners complain that certification is too expensive and the standards inappropriate for them. Fourth, the impact of certification is limited because slash and burn agriculture and the use of wood for fuel are much greater threats to forests in many countries. 


\section{REFERENCES}

Altbach, Philip G. 1973. Student Politics in America: an historical analysis. McGraw-Hill.

Applebaum, Richard, and Peter Dreier, The Campus Anti-Sweatshop Movement American Prospect, no. 46 Sept-Oct 1999.

AFL-CIO. Agents of Change, a handbook for student labor activists. 1999.

Benjamin, Medea. 1998. A Critique of Fair Labor Association (FLA), December. Available at www.citinv.it/associazioni/CNMS/archivio/strategie/doc_globalexchange.html; downloaded January 5, 2001.

Bernard, Elaine. 1997. Ensuring that Monitoring is Not Co-opted. New Solutions, vol. 7, no. 4 (Summer): 10-12.

Brown, Drusilla, Alan V. Deardorff, and Robert M. Stern. 1993. International Labor Standards and Trade: A Theoretical Analysis. In Jagdish N. Bhagwati and Robert E. Hudec, eds., Fair Trade and Harmonization: Prerequisites for Free Trade? Cambridge, MA: MIT University Press, 1996.

Bureau of National Affairs, "Developing Countries Reiterate Opposition to Trade-Labor Link." Daily Labor Reporter, November, 19 1999, p A-3.

CAFOD. 1998. Views from the South, Conference Report on Ethical Trade, September. Available at www.cafod.org.uk/policyviews.htm; downloaded July 13, 2000.

Charness, Gary, Ernan Haruvy, and Doron Sonsino. 2000. Social Distance and Reciprocity: An Internet Experiment. Department of Economics and Business, Universitat Pompeu Fabra Economics Working Papers. Barcelona.

Compa, Lance. 2000. NGO-Labor Union Tensions on the Ground. In Carnegie Council on Ethics and International Affairs, Human Rights Dialogue, series 2, no 4 (Fall): pp 12-14.

Coop America, Coop America Quarterly “Solutions to a Global Problem” no 46, fall 1998.

Duncan, Lauren E and Steward, Abigail, "Still Bringing the Vietnam War Home: sources of contemporary student activism" Personality and Social Psychology Bulletin, vol. 21 (Sept 1995), 914-24.

Duong, Trinh. 2000. Codes of Conduct Don't Work: A View from the Factory Floor. In Carnegie Council on Ethics and International Affairs, Human Rights Dialogue, series 2, no 4 (Fall): p. 5.

Elliott, Kimberly Ann. 2000. (Mis)managing Diversity: Worker Rights and US Trade Policy. International Negotiation, 5: 97-127. 
Fabian, Teresa. 1998. Social Accountability 8000(SA8000), January. Available at http://www.citinv.it/associazioni/CNMS/archivio/lavoro/Presentazione_SA8000.html; downloaded January 5, 2001.

Freeman, Richard. 1997. Working for Nothing: the supply of volunteer labor. Journal of Labor Economics, vol 15, part 2 (January).

Freeman, Richard. 1998. What Role for Labor Standards in the Global Economy. UN.

Freeman Richard 1999 "Spurts in Union Growth: Defining Moments and Social Processes" in The Defining Moment: The Great Depression and the American Economy in the Twentieth Century (Michael D. Bordo, Claudia Goldin, and Eugene N. White, editors). Chicago: University of Chicago Press for the National Bureau of Economic Research.

Frost, Stephen. 2000. Factory Rules Versus Codes of Conduct. In Carnegie Council on Ethics and International Affairs, Human Rights Dialogue, series 2, no 4 (Fall): p 4.

Feuer, Lewis S. 1969. The conflict of generations; the character and significance of student movements. New York: Basic Books.

Global Exchange. A Directory of US anti-sweatshop organizations, 1999.

Hoberg, George. 1999. The Coming Revolution in Regulating our Forests. Policy Options (Montreal), December.

Hufbauer, Gary Clyde, Jeffrey J. Schott, and Kimberly Ann Elliott. Economic Sanctions Reconsidered. 3rd edition, forthcoming. Washington: Institute for International Economics.

International Labor Organization. 2000. Labour practices in the footwear, leather, textiles and clothing industries, Report for discussion at the Tripartite Meeting on Labour Practices in the Footwear, Leather, Textiles and Clothing Industries. Geneva: International LaborOffice.

1998. Overview of global developments and Office activities concerning codes of conduct, social labelling and other private sector initiatives addressing labour issues. Report to the Governing Body of the Working Party on the Social Dimension of the Liberalization of International Trade. GB.273/WP/SDL/1(Rev. 1). 273rd Session. Geneva, November.

Kahneman, Daniel, and Amos Tversky. 1979. Prospect Theory: An analysis of decision under risk. Econometrica, vol. 47, no. 2: 263-291.

Keck, Margaret E., and Kathryn Sikkink. 1998. Activists Beyond Borders: Advocacy Networks in International Politics. Itacha, NY: Cornell University Press.

Klein, Naomi. 1999. No Logo: Taking Aim at the Brand Bullies. New York: Picador USA.

Liubicic, Robert J. 1998. Corporate Codes of Conduct and Product Labeling Schemes: The Limits and Possibilities of Promoting International Labor Rights Through Private Initiatives. Law and Policy in International Business, vol. 30, no. 1 (Fall): 112-58. 
Marymount University Center for Ethical Concerns. 1999. The Consumers and Sweatshops, November. Available at www.marymount.edu/news/garmentstudy/overview.html; downloaded January $5,2001$.

Massie, Robert Kinloch. 1997. Loosing the Bonds: The United States and South Africa in the Apartheid Years. New York: Doubleday.

McAdam, Doug "Recruitment to High Risk Activism: the case of Freedom Summer'American Journal of Sociology, v 92, July 1986, pp 64-90

McAdam, Doug "Specifying the Relationship Between Social Ties and Activism”American Journal of Sociology, v 99 Nov1993, pp 640-667

McAdam, Doug “The Biographical Consequences of Activism”American Sociological Review, v 54, Oct 1989, pp 744-760

Moore, David. 2000. Speaking with a Unified Voice: Student Consumers Make Targeted Change. In Carnegie Council on Ethics and International Affairs, Human Rights Dialogue, series 2, no 4 (Fall): p. 10-11.

O'Rourke, Dara. 2000. Monitoring the Monitors: A Critiquie of Price Waterhouse Coopers (PWC) Labor Monitoring. Massachusetts Institute of Technology, September 28. Available at http://web.mit.edu/dorourke/www; downloaded October 2000.

Oxfam. 1998-99. Levi's Works with Oxfam on Updated Codes of Conduct. Oxfam Campaigner, (Winter); available at www.oxfam.org.uk/campaign/campaigner.

Queenan, Joe. 2000. My Goodness: A Cynic's Short-lived Search for Sainthood. New York: Hyperion Press.

Rothstein, Richard. 1996. The Starbucks Solution: Can Voluntary Codes Raise Global Living Standards. The American Prospect, no. 27 (July-August): 36-42.

Sabel, Charles, Dara O'Rourke, and Archon Fung. "Ratcheting Labor Standards." Unpublished, May 2000 .

Soule, Sarah, "The Student Divestment Movement in the US" Social Forces March 1997, 75(3), 855-883.

Starbucks. 2000. Starbucks and TransfairUSA Enter into Breakthrough Alliance, April 10. Available at www.starbucks.com/company/pressde.

UN Food and Agricultural Organization. 2000. State of the World's Forests 1999. Rome. 
US Department of Labor, Bureau of International Labor Affairs. 2000. Wages, Benefits, Poverty Line, and Meeting Workers' Needs in the Apparel and Footwear Industries of Selected Countries. Washington, February.

United Students Against Sweatshops. 1999. "College Clothes from the Concrete Prison, July. Timeline of USAS, www.umich.edu/ sole/usas/history Campaign www.umich.edu/ sole/usas/campaign Sweatshop-Free Campus Campaign Organizer's Manual

University of Maryland, Program on International Policy Attitudes. 2000. Americans on Globalization: A Study of Public Attitudes. College Park, MD, March. Available at: www.pipa.org/OnlineReports/Globalization/global_rep.html.

Van Dyke, Nella "Hotbeds of Activism: locations of student prot Social Problems, vol 45, no 2, May 1998, p 205-220.

Varley, Pamela, editor. 1998. The Sweatshop Quandary: Corporate Responsibility on the Global Frontier. Washington: Investor Responsibility Research Center.

Verite, Dynamics of the Global Assembly Line, www.verite.org/dynamics_verite.html (downloaded 7/12/00).

Wall Street Journal, Editorial Page "Capitalism 101", 11/30/1998, p A22

Weil, David. 2000. "Everything Old is New Again: Regulating Labor Standards in the U.S. Apparel Proceedings, 52nd Meeting of the Industrial Relations Research Association.

Winston, Morton. Forthcoming. "NGO Strategies for Promoting Global Corporate Social Responsibility." In Robin Hodess, ed., Justice in the World Economy: Globalization, Agents, and the Pursuit of Social Good. New York: Carnegie Council on Ethics and International Affairs.

Wisconsin, Lafollette Center. 1999. Economic Effects of Setting Living Wage Standards. (Robert Pollin and David Moore), Nov 18-21. 
EXHIBIT 1: Survey Findings on Consumers Expressed Desire for Labor Standards

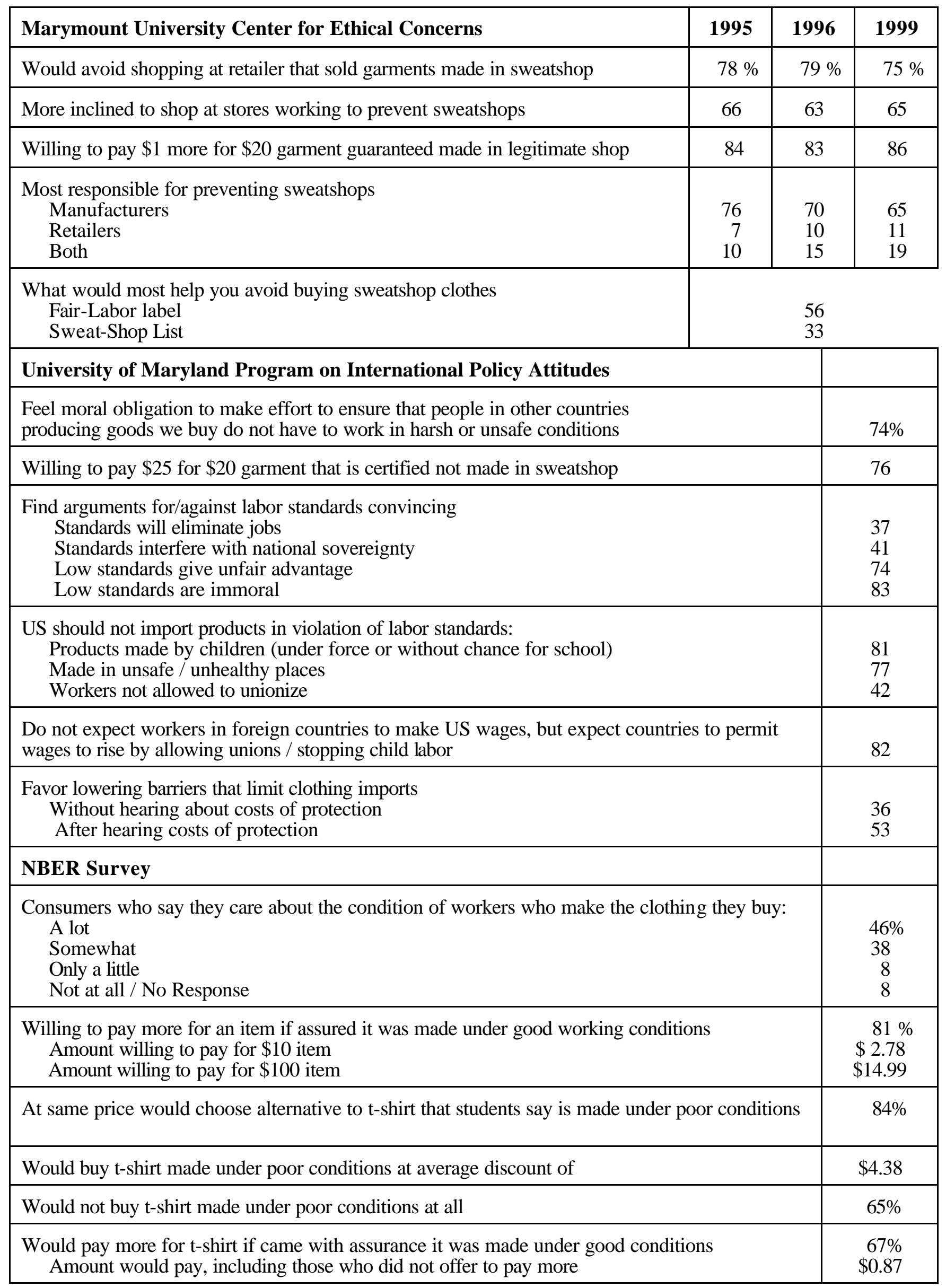


EXHIBIT 2: Estimated Demand Curves for Standards

Panel A

\$10 Item Made Under Good Conditions

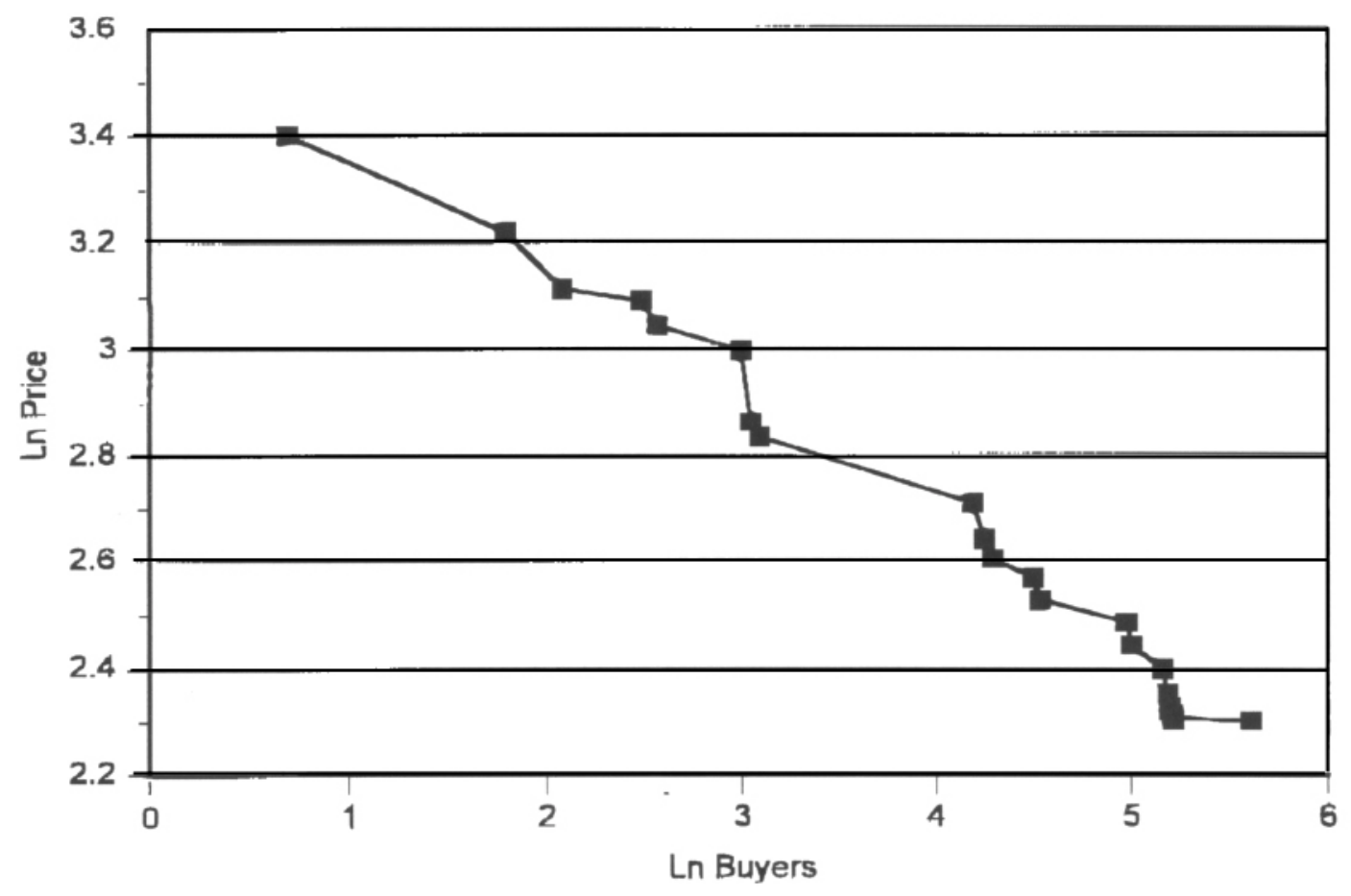

$\$ 100$ Item made Under Good Conditions

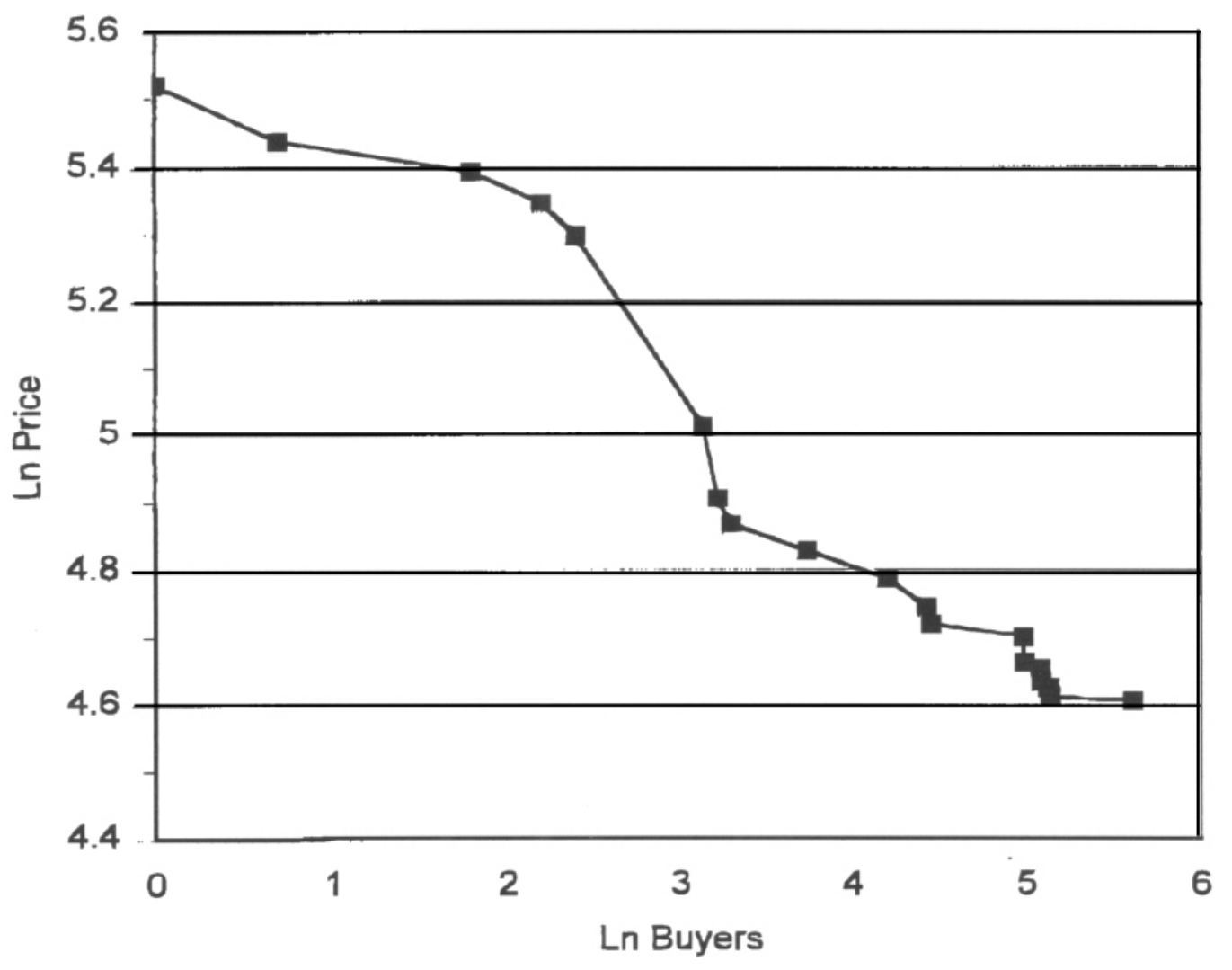


EXHIBIT 2 (continued)

Panel B

Pay for $\$ 10$ T shirt Under Good Conditions

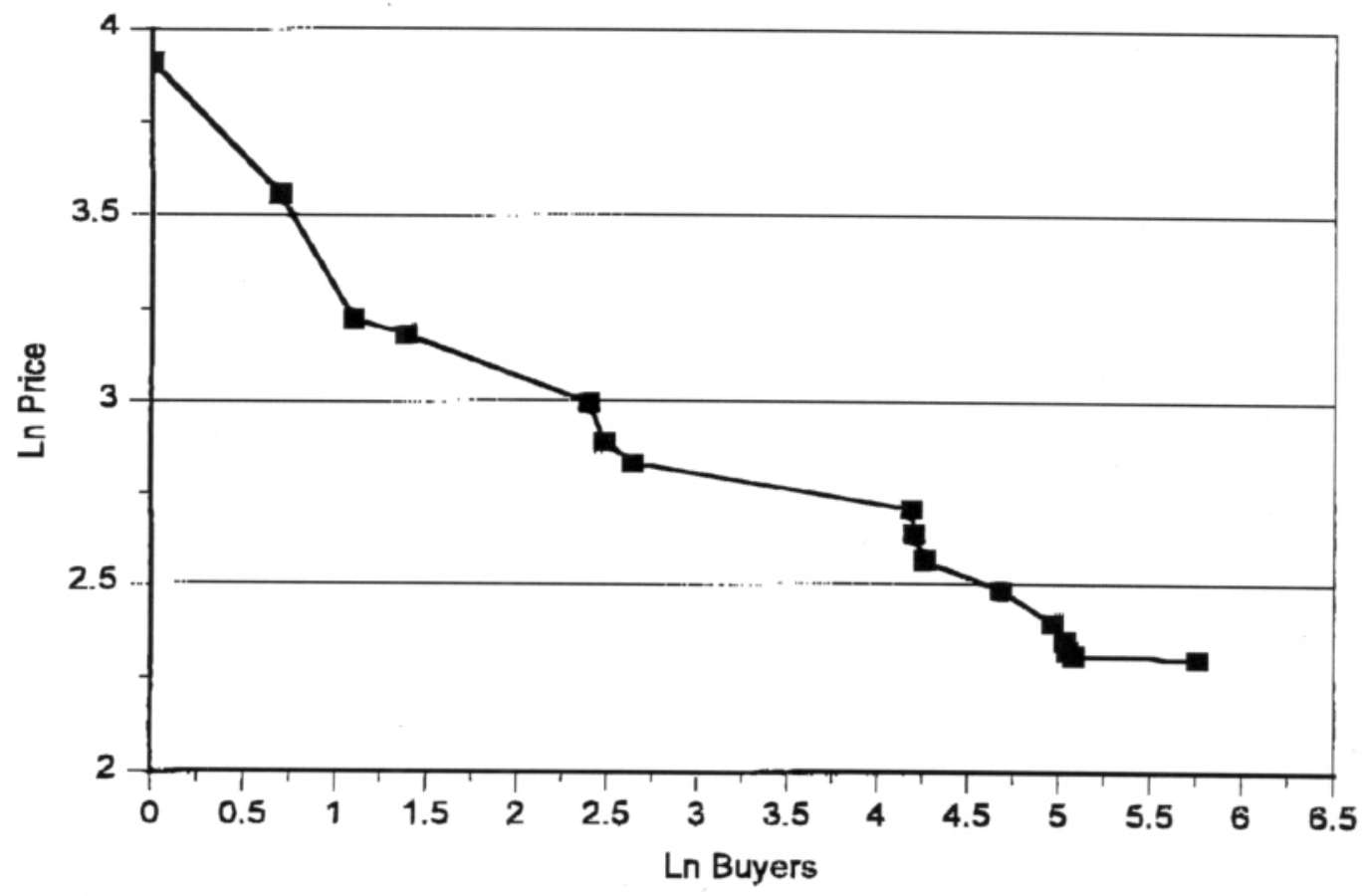

Panel C

Pay for \$10 T-shirt Under Bad Conditions

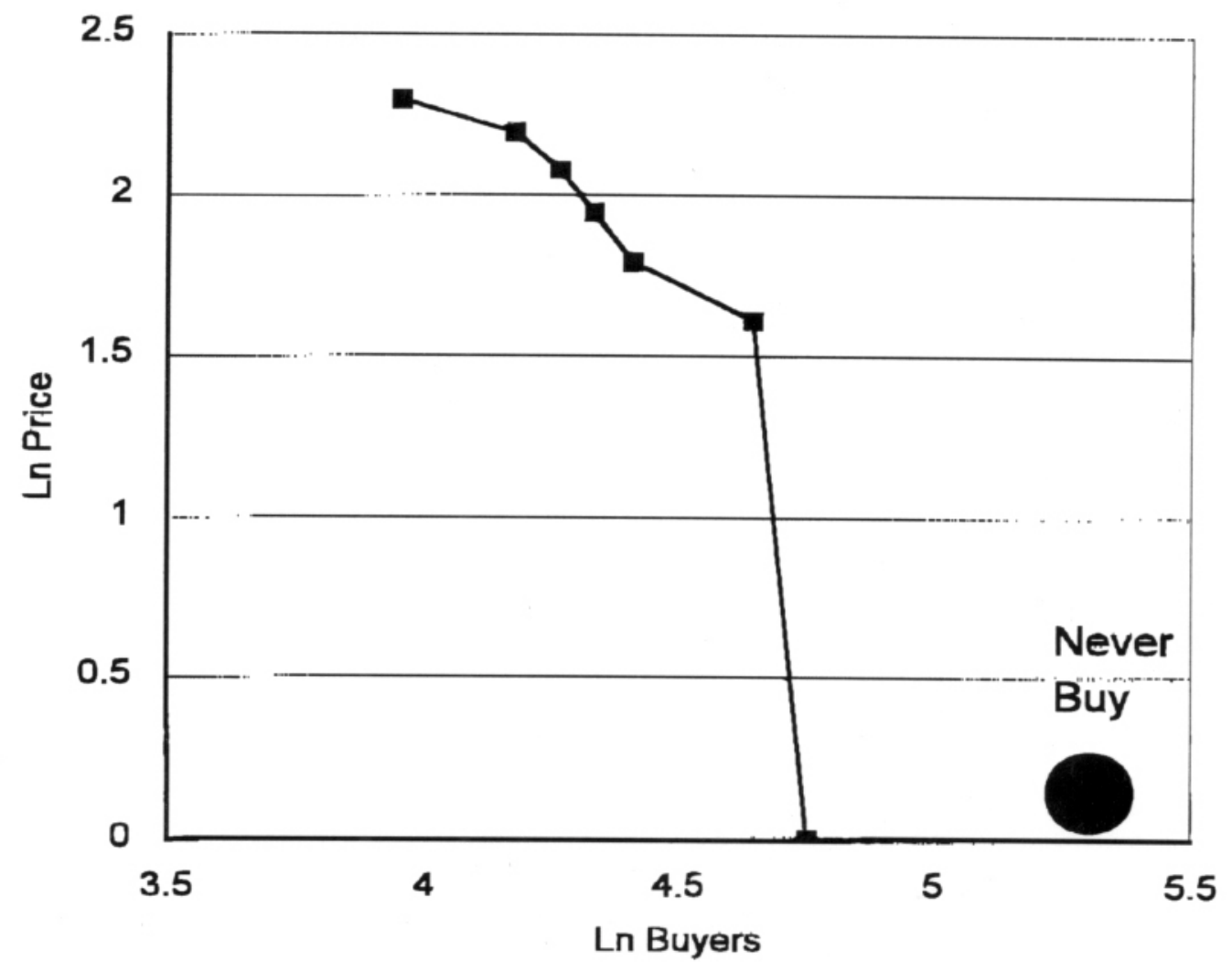




\section{EXHIBIT 3}

\section{The Chain of Production: Retail to Factory}

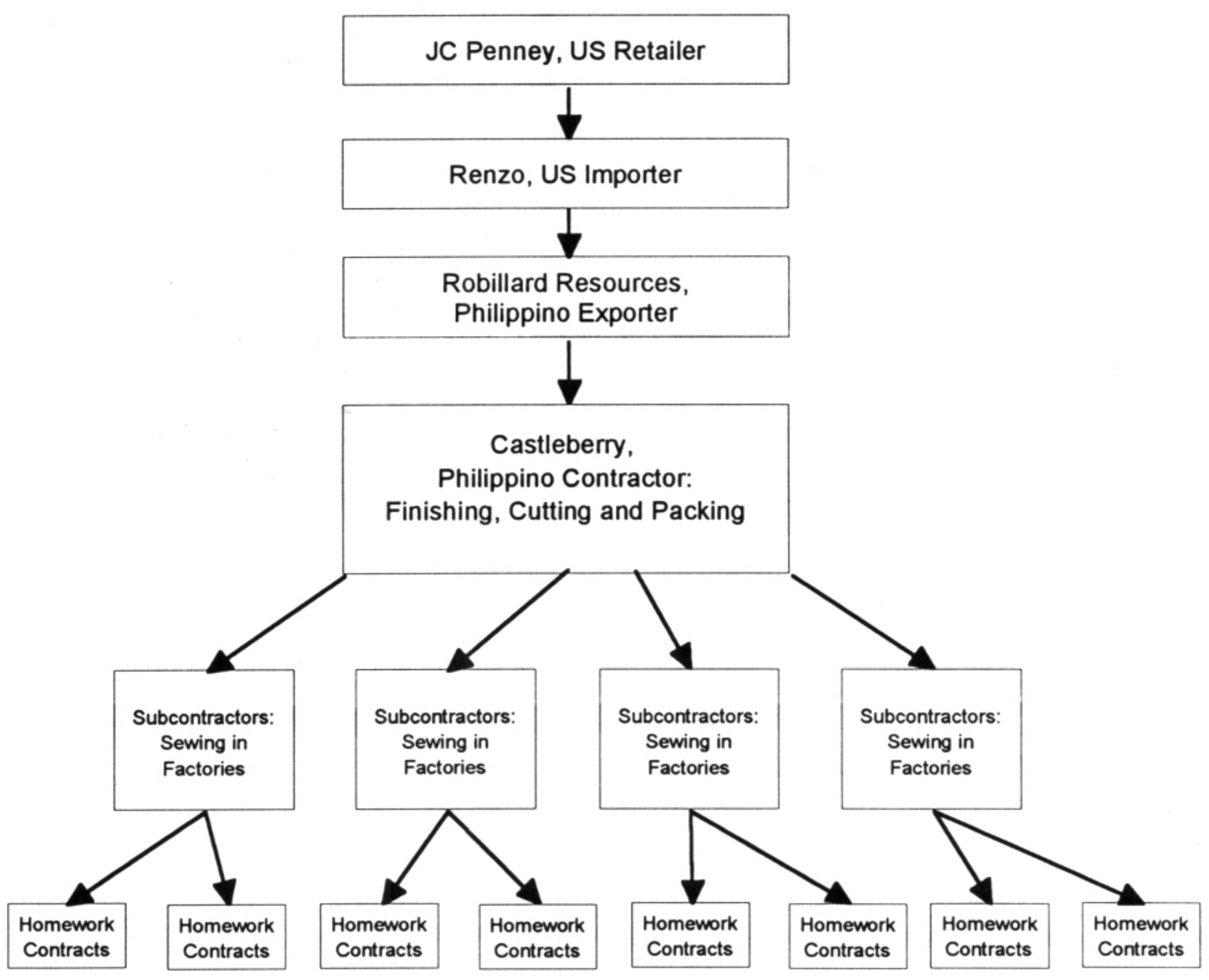




\section{EXHIBIT 4: Incentives to Improve Standards}

\section{Prices, Costs}

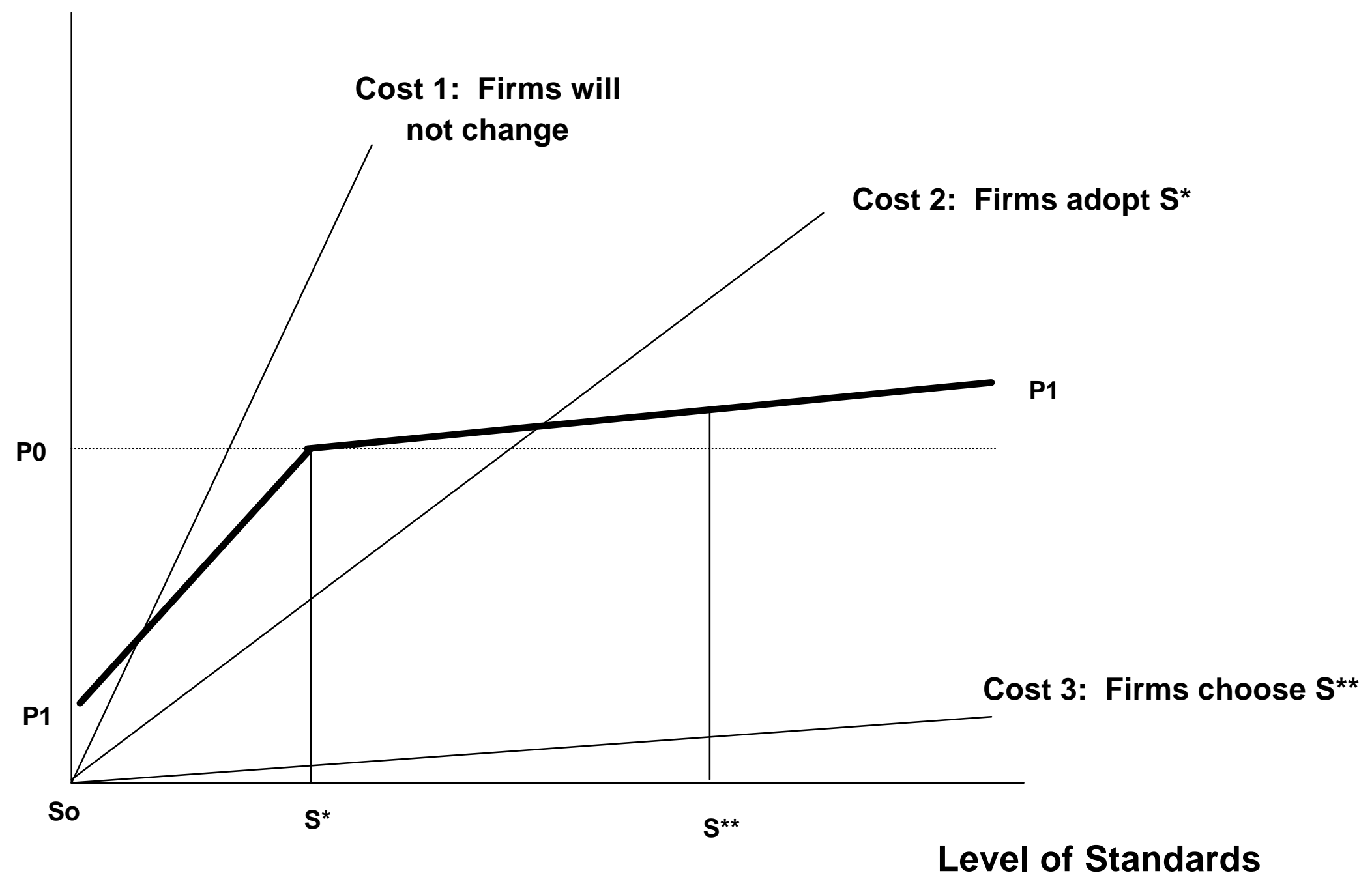

$\mathrm{PO}=$ price before campaign

P1 = price after campaign 
EXHIBIT 5: Characteristics of Student Anti-Sweatshop Activists

\begin{tabular}{|c|c|}
\hline A. Family Background & Percentage \\
\hline $\begin{array}{l}\text { Family Income }^{\mathrm{a}} \\
\quad>100,000 \\
75-100,000 \\
40-75,000 \\
\quad<40,000\end{array}$ & $\begin{array}{l}36 \\
22 \\
34 \\
8\end{array}$ \\
\hline $\begin{array}{l}\text { Political Attitudes of Parents } \\
\text { Progressive } \\
\text { Non-Partisan } \\
\text { Conservative }\end{array}$ & $\begin{array}{l}40 \\
27 \\
34\end{array}$ \\
\hline $\begin{array}{l}\text { Involved in activism in college } \\
\text { Involved in activisim after college }\end{array}$ & $\begin{array}{l}29 \\
25\end{array}$ \\
\hline $\begin{array}{cc}\begin{array}{c}\text { Attitude of Others to Involvement } \\
\text { Parents: }\end{array} & \begin{array}{c}\text { supportive } \\
\text { critical } \\
\text { supportive } \\
\text { critical }\end{array} \\
\text { Professors: } & \begin{array}{c}\text { crictive } \\
\text { critical }\end{array} \\
\text { Uninvolved friends: } & \text { suportive }\end{array}$ & $\begin{array}{r}58 \\
11 \\
67 \\
24 \\
37 \\
7\end{array}$ \\
\hline B. Orientation Toward Social Activism & Percentage \\
\hline $\begin{array}{l}\text { Involved in activism before } \\
\text { High School } \\
\text { College } \\
\text { Ever member of trade union } \\
\text { Involved in Union Summer } \\
\text { View self as politically committed activist (rather than apolitical do-gooder) }\end{array}$ & $\begin{array}{r}52 \\
84 \\
31 \\
9 \\
90\end{array}$ \\
\hline $\begin{array}{l}\text { \% Rating Happiness as } 9-10 \text { on } 10 \text { point scale } \\
\text { All A s } \\
\text { Living wage agreed to by corps and labor } \\
\text { Collegiate licensing companies agreed to full disclosure of factory locations } \\
\text { US unions increase share of work force } \\
\text { US cancels debt to third world countries }\end{array}$ & $\begin{array}{l}48 \\
81 \\
69 \\
68 \\
74\end{array}$ \\
\hline C. Allocation of Time & \\
\hline $\begin{array}{l}\text { Hours per Week on anti-sweatshop activities } \\
\text { Hours per Week on other extra-curricular activities } \\
\text { Hours per Week Studying } \\
\text { Held Job } \\
\quad \text { Hours if held job }\end{array}$ & $\begin{array}{l}6.2 \mathrm{hrs} \\
10.3 \mathrm{hrs} \\
14.3 \mathrm{hrs} \\
40 \% \\
10.8 \mathrm{hrs}\end{array}$ \\
\hline $\begin{array}{l}\text { If not involved, would spent time on } \\
\text { Another cause } \\
\text { Arts / Athletics } \\
\text { Socializing } \\
\text { Schoolwork } \\
\text { Sleep }\end{array}$ & $\begin{array}{l}47 \\
36 \\
30 \\
27 \\
13\end{array}$ \\
\hline D. Net Effect of Anti-Sweatshop Efforts & Percentage \\
\hline $\begin{array}{l}\text { Net Effect on (minus sign indicates negative): } \\
\text { Grades } \\
\text { Romantic Life } \\
\text { Friendships } \\
\text { Self-Confidence } \\
\text { Communication and Leadership Skills }\end{array}$ & $\begin{array}{r}-16 \\
3 \\
46 \\
76 \\
83\end{array}$ \\
\hline
\end{tabular}

a. For comparison, in the UCLA/ACE Freshman Survey, the proportion in these categories was:

Family Income: > 100,000 - 16\%; 75-100,000 - $12 \%$; 40-75,000 - 36\%; <40,000 - 35\%.

Source: Tabulated from Survey of Student Activisits. 
EXHIBIT 6: Activists Compared to College Freshmen Overall

\begin{tabular}{|l|c|c|}
\hline & Activists & $\begin{array}{c}\text { College Freshmen } \\
\text { Overall }\end{array}$ \\
\hline Agree strongly or somewhat & & $42 \%$ \\
\hline Sex OK if people really like each other & $81 \%$ & 20 \\
Racial discrimination no longer a problem & 1 & 64 \\
Prohibit racist / sexist speech & 38 & 63 \\
Wealthy should pay more taxes & 93 & 37 \\
Disobey laws that violate values & 74 & 33 \\
Individual can do little to change society & 9 & \\
\hline Deems essential or very important & & 63 \\
\hline Becoming authority in field & 52 & 73 \\
Raising family & 46 & 75 \\
Be very well off financially & 6 & 17 \\
Influence political structure & 84 & 31 \\
Be community leader & 70 & \\
\hline
\end{tabular}

Source: Tabulated from Activist Survey; ACE/UCLA survey of College Freshman, 1998. 
EXHIBIT 7: Timeline of Anti-sweatshop Activities

1990

1992

1992

1993

August 1993

March 1995

August 1995

December 1995

Spring 1996

August 1996

March 1997

April 1997

August 1997

October 1997

April 1998

Spring 1998

Summer 1998
Charles Kernaghan becomes director of National Labor Committee (NLC), founded in 1981 to oppose Reagan administration policies in Central America.

Levi Strauss develops first code of conduct for suppliers following DOL suit against contractors in Saipan over wages, etc.; a year later, Levi's announces plans to withdraw from China because of human rights situation there.

Senator Tom Harkin (D-IA) introduces bill to bar imports of goods produced using child labor; reintroduces in each Congress until 1997 when he substitutes legislation calling for beefed up enforcement of existing law barring imports of goods produced with forced labor, including bonded or other forced child labor.

Wal-Mart publishes "Standards for Vendor Partners" after televised revelations regarding child labor use by suppliers in Bangladesh.

Clinton administration negotiates side agreements on labor and environment to accompany North American Free Trade Agreement.

Criticized for "de-linking" human rights from most-favored nation trade status for China in 1994, Clinton administration releases "model business principles" to encourage MNCs to adopt voluntary codes of conduct in operations around the world.

Department of Labor closes down sweatshop in El Monte California after discovering immigrant Thai workers being forced to work in slave-like conditions; incident gives momentum to Secretary Robert Reich's campaign to combat sweatshops in US.

Under pressure from NLC, People of Faith Network over working conditions in El Salvador, The Gap agrees to independent monitoring of contractor facility.

NLC's Kernaghan reveals Wal-Mart clothing endorsed by television personality Kathie Lee Gifford is produced under exploitative conditions, including child labor; Gifford vows to remedy situation; second scandal involving Gifford-endorsed clothing produced in American sweatshops in New York leads to collaboration with Labor Secretary Reich on his "No Sweat" campaign.

President Clinton, Secretary Reich announce creation of Apparel Industry Partnership, bringing together retailer/importers, unions, and NGOs to address sweatshop issue.

Management in a Phillips-Van Heusen (PVH) contract facility in Guatemala recognizes union, a first in that country's apparel export sector.

AIP report outlines "Workplace Code of Conduct" and "Principles of Monitoring".

Duke University students form group called Students Against Sweatshops; in subsequent months, movement grows on campuses across country eventually becoming United Students Against Sweatshops (USAS).

Council on Economic Priorities, following consultations with companies and NGOs, releases plan for "social audit" dealing with worker rights, creates agency to accredit compliance monitors.

Levi Strauss announces its return to China, arguing that the human rights situation has improved sufficiently "that the overall environment now is such that the risks to our Financial Times, 8 April 1998).

Under pressure from student group, Duke University releases code of conduct for suppliers of apparel licensed by Duke to display the university name or logo; code calls for independent monitoring of compliance, through the AIP if appropriate, and requires suppliers to disclose names and addresses of all contractors and plants involved in production of Duke-licensed apparel.

UNITE commits interns and resources to helping establish USAS on national basis. 


\section{EXHIBIT 7 (continued)}

August 1998

November 1998

December 1998

January 1999

Early 1999

October 7, 1999

October 19, 1999

December 1999

December 9, 1999

Spring 2000
Joint NLC-USAS delegation visits Central America to meet workers, NGOs.

AIP agrees on creation of Fair Labor Association and accreditation of independent monitors to monitor compliance with code.

PVH closes unionized plant in Guatemala, saying it lost a major contract and has excess capacity; production will continue at nonunion plants elsewhere in Guatemala.

UN Secretary General Kofi Annan, at World Economic Forum in Davos, Switzerland, announces new "Global Compact" calling on the business community to respect basic principles on human rights, worker rights, and protection of the environment, but with no means for monitoring of compliance. NGOs followed a year later with a ACitizens' Compact" that rejects "partnership" between the UN and the business community and calls on the UN to make the principles mandatory with provisions for monitoring.

USAS criticizes universities for signing on to FLA model for monitoring without consulting them; students hold sit-ins to demand stronger code at Duke, Georgetown, Wisconsin, North Carolina, and, for 226 hours, Arizona. In April, USAS releases detailed report on inadequacies of FLA code and monitoring process and gives universities until October 15 to seek improvements.

Under pressure from USAS and universities, Nike discloses locations of 41 factories producing licensed apparel for Duke, UNC, Georgetown, Michigan, and Arizona.

After rejection by FLA of their suggestions and passage of the 6-month deadline with no other action by universities, USAS announces alternative Worker Rights Consortium and calls on universities to withdraw from FLA. Brown University is the first to respond, announcing that it will join the WRC but also remain in the FLA; others, including Phil Knight alma mater University of Oregon follow.

Liz Claiborne agrees to independent monitoring at supplier facility in El Salvador; report published in full on International Labor Rights Fund website (see appendix).

Philadelphia City Council calls on area colleges and universities to join WRC.

Nike retaliates against Brown and the University of Oregon for joining WRC, terminates contract to provide hockey products in one case and ends personal and corporate philanthropic relations in the other. 
EXHIBIT 8 Key Differences among the Major Monitoring Initiatives

\begin{tabular}{|c|c|c|c|c|}
\hline Initiative & Code content & Monitoring procedures & Disclosure & Certification \\
\hline FLA & $\begin{array}{l}\text { Living wage: code notes "wages are } \\
\text { essential to meeting employees' basic } \\
\text { needs," but requires only that firms } \\
\text { pay minimum or prevailing wage. } \\
\text { Union rights: requires employers to } \\
\text { respect; separate section of charter } \\
\text { notes that "special guidelines" may be } \\
\text { required for countries where rights in } \\
\text { code not respected in law or practice, } \\
\text { prohibits factory owners using } \\
\text { violence or requesting help of state } \\
\text { authorities to discourage organizing. }\end{array}$ & $\begin{array}{l}\text { Corporate members must do internal } \\
\text { monitoring, as well as submit to external } \\
\text { monitoring by FLA - approved agencies. } \\
\text { Initially, } 30 \text { percent of suppliers, suggested } \\
\text { by member company based on certain "risk } \\
\text { factors," will be inspected periodically; the } \\
\text { proportion eventually drops to } 10 \text { percent, } \\
\text { which may be adjusted up or down } 5 \\
\text { percent. FLA executive director can adjust } \\
\text { list of factories if necessary or appropriate } \\
\text { and sample size will also be reviewed for } \\
\text { adequacy as monitoring proceeds. } \\
\text { There are also procedures for third parties } \\
\text { to submit complaints to the executive } \\
\text { director for investigation. } \\
\text { To encourage participation, FLA } \\
\text { reimburses half of costs of external } \\
\text { monitoring in first year, declining to } 30 \\
\text { percent in the third year and } 0 \text { in the fifth. }\end{array}$ & $\begin{array}{l}\text { Corporate members must submit a list of } \\
\text { suppliers to the FLA but it remains } \\
\text { confidential; FLA also does not release } \\
\text { either internal or external monitoring } \\
\text { reports, but will publish annual summary } \\
\text { reports for each member company. }\end{array}$ & $\begin{array}{l}\text { Requires remediation of } \\
\text { any violations found } \\
\text { and report to FLA on } \\
\text { steps taken both to } \\
\text { resolve problems and to } \\
\text { prevent recurrence in } \\
\text { future. } \\
\text { After monitoring system } \\
\text { is tested and evaluated, } \\
\text { it is anticipated that } \\
\text { member companies will } \\
\text { be able to use service } \\
\text { mark for specific brands } \\
\text { certified as in } \\
\text { compliance with FLA } \\
\text { code. }\end{array}$ \\
\hline $\begin{array}{l}\text { Social } \\
\text { Accountability } \\
\text { International } \\
\text { (previously } \\
\text { CEPAA) }\end{array}$ & $\begin{array}{l}\text { Living wage: Does not use this phrase } \\
\text { but requires wages that "shall always } \\
\text { be sufficient to meet basic needs of } \\
\text { personnel and to provide some } \\
\text { discretionary income;" the guidance } \\
\text { document notes this may be above the } \\
\text { prevailing wage and suggests criteria } \\
\text { for calculating basic needs similar to } \\
\text { those used for calculating living } \\
\text { wages. } \\
\text { Union rights: Must be respected; } \\
\text { where such rights are restricted by law, } \\
\text { requires firms to "facilitate parallel }\end{array}$ & $\begin{array}{l}\text { Manufacturing plants must be certified by } \\
\text { an accredited SAI monitor as in } \\
\text { compliance with the SA } 8000 \text { standard; } \\
\text { accreditation and certification are good for } \\
\text { three years with continuing surveillance of } \\
\text { certified plants every six months. The } \\
\text { plant seeking certification selects an } \\
\text { auditor from the list of SAI-accredited } \\
\text { agencies and bears all costs of audit. } \\
\text { SAI also provides a procedure for } \\
\text { complaints and appeals of certification } \\
\text { decisions by interested parties. }\end{array}$ & $\begin{array}{l}\text { List of certified firms is available on SAI } \\
\text { website. } \\
\text { Corporate members must release annually } \\
\text { a public report describing objectives and } \\
\text { reporting statistics on their progress in } \\
\text { getting their suppliers certified. } \\
\text { Accredited auditors do not release reports, } \\
\text { but code requires that certified firms } \\
\text { "establish and maintain procedures to } \\
\text { communicate regularly to all interested } \\
\text { parties data and other information } \\
\text { regarding performance against the }\end{array}$ & $\begin{array}{l}\text { Requires remediation of } \\
\text { any problems found and } \\
\text { confirmation of same by } \\
\text { auditor. } \\
\text { Allows certified plants } \\
\text { to display certificate in } \\
\text { catalogue, on stationery, } \\
\text { and in advertising but } \\
\text { may not place label on } \\
\text { product. }\end{array}$ \\
\hline
\end{tabular}




\begin{tabular}{|c|c|c|c|c|}
\hline & $\begin{array}{l}\text { means of independent and free } \\
\text { association and bargaining for all such } \\
\text { personnel." }\end{array}$ & $\begin{array}{l}\text { Corporations involved in retail sales can } \\
\text { be SAI members if they commit to } \\
\text { encouraging suppliers to become certified } \\
\text { and to "eventually" phase out relations } \\
\text { with substandard suppliers. }\end{array}$ & $\begin{array}{l}\text { requirements of this document, including, } \\
\text { but not limited to, the results of } \\
\text { management reviews and monitoring } \\
\text { activities." }\end{array}$ & \\
\hline WRC & $\begin{array}{l}\text { Living wage: code requires payment of } \\
\text { a "dignified living wage" but other } \\
\text { documents allow universities to } \\
\text { postpone implementation until further } \\
\text { research is completed. } \\
\text { Union rights: requires licensees to } \\
\text { respect and prohibits any form of } \\
\text { intimidation, retaliation or the barring } \\
\text { of organizers from premises. } \\
\text { In countries where laws conflict with } \\
\text { rights in code, licensees are } \\
\text { nevertheless to take action to "achieve } \\
\text { full compliance" and license } \\
\text { agreements may not be renewed for } \\
\text { goods produced in countries where } \\
\text { "compliance with the employment } \\
\text { standards in the Code is deemed } \\
\text { impossible." }\end{array}$ & $\begin{array}{l}\text { "Verification model" relies on disclosure } \\
\text { and "spot investigatory capacity" to } \\
\text { enforce code. WRC will create WRC } \\
\text { Agency to oversee investigations of } \\
\text { compliance but will not permit licensees to } \\
\text { be members or to influence process in any } \\
\text { way. Agency, funded by university } \\
\text { licensing revenue, will work with local } \\
\text { groups that are trusted by workers to } \\
\text { investigate complaints. }\end{array}$ & $\begin{array}{l}\text { Requires licensees to disclose name and } \\
\text { location of all factories producing licensed } \\
\text { apparel, as well as "objective measures" of } \\
\text { working conditions, including wages and } \\
\text { benefits, work hours, etc. Also requires } \\
\text { licensees to ensure access on demand to } \\
\text { company records and workplace. }\end{array}$ & $\begin{array}{l}\text { Licensees are threatened } \\
\text { with termination of } \\
\text { contract if suppliers not } \\
\text { in compliance with code } \\
\text { but no licensee will be } \\
\text { certified as in } \\
\text { compliance because not } \\
\text { possible to monitor all } \\
\text { plants all the time. }\end{array}$ \\
\hline
\end{tabular}

Sources: Based on organizing documents from the groups, most of which are available on their websites: fairlabor.org for FLA; cepaa.org for SAI; workersrights.org for WRC. For other comparisons, see also, "Assessment of the Fair Labor Association Agreement" on the International Labor Rights Fund website (laborrights.org), "A renewed analysis of the Fair Labor Association..." on the United Students Against Sweatshops website (umich.edu/ sole/usas/), the response on the FLA website, and the report by the University of Michigan Advisory Committee on Labor Standards and Human Rights, http://www.umich.edu/ newsinfo/BG/humright.html. 
EXHIBIT 9: Assessment of Selected Anti-Sweatshop Campaigns (italics indicates member of FLA)

\begin{tabular}{|c|c|c|c|c|}
\hline $\begin{array}{l}\text { Company or } \\
\text { Campaign }\end{array}$ & Influence on Procedures & Influence on Behavior & Assessment* & Comments \\
\hline Disney & $\begin{array}{l}\text { None: has a code but refused to respond } \\
\text { to NLC campaign on Haiti (except by } \\
\text { allowing one licensee to withdraw) }\end{array}$ & None detected. & -1 to 0 & $\begin{array}{l}\text { Young children difficult to mobilize and } \\
\text { parents reluctant to say no. }\end{array}$ \\
\hline Levi Strauss & $\begin{array}{l}\text { Early promoter of code; traditionally } \\
\text { opposed independent monitoring but } \\
\text { recently joined FLA, ETI in Europe. }\end{array}$ & $\begin{array}{l}\text { In 1993, announced withdrawal from China } \\
\text { because of human rights abuses, later } \\
\text { stopped sourcing in Burma }\end{array}$ & 3 & $\begin{array}{l}\text { Levi Strauss has always promoted itself as } \\
\text { caring about workers in US and abroad; } \\
\text { but sales down, profits under pressure in } \\
\text { recent years; froze withdrawal from China } \\
\text { in 1996, announced expansion in 1998, } \\
\text { closed plants in US and Western Europe. }\end{array}$ \\
\hline $\begin{array}{l}\text { Liz Claiborne, } \\
\text { Inc. }\end{array}$ & $\begin{array}{l}\text { Accepted independent NGO monitoring at } \\
\text { contract facility in El Salvador }\end{array}$ & $\begin{array}{l}\text { Shortfalls identified and publicly reported; } \\
\text { need to verify remediation }\end{array}$ & $2-3$ & $\begin{array}{l}\text { Experiment not replicated but presumably } \\
\text { will be through FLA }\end{array}$ \\
\hline Nike & $\begin{array}{l}\text { Has been much more open; though } \\
\text { criticized, hired Andrew Young group to } \\
\text { monitor facilities in East Asia; revealed } \\
\text { locations of factories producing licensed } \\
\text { university apparel }\end{array}$ & $\begin{array}{l}\text { Like Reebok is eliminating toxic solvents } \\
\text { from production process; has improved } \\
\text { ventilation in factories; raised wages } \\
\text { above official minimum wage after Asian } \\
\text { financial crisis }\end{array}$ & $2-3$ & $\begin{array}{l}\text { Criticism of Young report (nothing on } \\
\text { wages); Corpwatch releases leaked Ernst } \\
\& \text { Young audit showing violations of } \\
\text { Vietnamese law, but concludes plant in } \\
\text { compliance with Nike code of conduct. }\end{array}$ \\
\hline $\begin{array}{l}\text { Phillips-Van } \\
\text { Heusen }\end{array}$ & $\begin{array}{l}\text { Asked Human Rights Watch to } \\
\text { investigate complaints at Guatemalan } \\
\text { facility }\end{array}$ & $\begin{array}{l}\text { Following Human Rights Watch report, } \\
\text { recognized union in Guatemala maquila }\end{array}$ & $1-2$ & $\begin{array}{l}\text { CEO Klatsky on board of HRW; direct } \\
\text { ownership stake in facility. } \\
\text { Shut plant after union recognized }\end{array}$ \\
\hline Reebok & $\begin{array}{l}\text { Early adoption of code; recently elicited } \\
\text { and published NGO report on factories } \\
\text { producing } 2 / 3 \text { of Reebok footwear in } \\
\text { Indonesia }\end{array}$ & $\begin{array}{l}\text { Report also included steps taken by } \\
\text { contractors to address health and safety } \\
\text { problems identified in NGO report; ; raised } \\
\text { wages above official minimum wage after } \\
\text { Asian financial crisis; like Nike is } \\
\text { eliminating toxic solvents from production } \\
\text { process }\end{array}$ & 3 & $\begin{array}{l}\text { Reebok letter accompanying NGO report } \\
\text { says too expensive to replicate elsewhere, } \\
\text { though hopes to apply lessons; critics } \\
\text { target failure to independently inspect all } \\
\text { factories producing for Reebok and for } \\
\text { not doing enough on wages. }\end{array}$ \\
\hline Starbucks & $\begin{array}{l}\text { In } 1995 \text {, following picketing/leafleting at } \\
\text { stores by US/Guatemala Labor Education } \\
\text { Project, announces a code of conduct for } \\
\text { coffee pickers in Guatemala, elsewhere. }\end{array}$ & $\begin{array}{l}\text { Announced action plan to assist small- } \\
\text { scale coffee producers improve quality } \\
\text { and expand overseas markets but takes no } \\
\text { steps to monitor code implementation. }\end{array}$ & 2 & $\begin{array}{l}\text { Starbucks promotes itself as socially- } \\
\text { conscious company, provides benefits to } \\
\text { part-time employees, donates profits to } \\
\text { charity (largest direct corporate } \\
\text { contributor to CARE according to }\end{array}$ \\
\hline
\end{tabular}




\begin{tabular}{|l|l|l|l|l|}
\hline & $\begin{array}{l}\text { In 2000, pre-empts planned protests at } \\
\text { stores in Washington, DC and elsewhere } \\
\text { by announcing it will buy and sell Fair } \\
\text { Trade Coffee. }\end{array}$ & $\begin{array}{l}\text { As of Fall 2000, Fair Trade coffee beans } \\
\text { are available in selected Starbucks stores. }\end{array}$ & promotional material in store). \\
\hline The Gap & $\begin{array}{l}\text { Accepted independent NGO monitoring at } \\
\text { contract facility in El Salvador }\end{array}$ & $\begin{array}{l}\text { Improvements in covered facilities; but } \\
\text { still no union recognition }\end{array}$ & $1-2$ & $\begin{array}{l}\text { Experiment has not been replicated in } \\
\text { other facilities and The Gap has refused to } \\
\text { settle case regarding sweatshop practices } \\
\text { in suppliers in Saipan that would provide } \\
\text { for independent monitoring by Verite, as } \\
\text { well as cash settlement for workers. }\end{array}$ \\
\hline $\begin{array}{l}\text { Wal-Mart and } \\
\text { Kathie Lee }\end{array}$ & $\begin{array}{l}\text { Wal-Mart adopted code early and KLG } \\
\text { agreed to ensure independent monitoring } \\
\text { to enforce code in facilities supplying } \\
\text { KLG-label clothing. Publicity contributed } \\
\text { to creation of AIP but, while KLG joined, } \\
\text { Wal-Mart did not. }\end{array}$ & None detected? & 1 & $\begin{array}{l}\text { Independent monitoring has not occurred } \\
\text { and allegations about facilities in China } \\
\text { and elsewhere continue; Wal-Mart also a } \\
\text { defendant in Saipan sweatshop case. }\end{array}$ \\
\hline
\end{tabular}

* From 1 for negative outcome to 5 for very successful. 


\section{ENDNOTES}

${ }^{1}$ Comparing the Marymount and PIPA surveys, we see that a higher premium on a \$20 item, \$5 versus $\$ 1$, reduces the number of people who say they would buy the product made under good conditions. In this range, moreover, the demand would appear to be modestly inelastic. Total revenues would rise with the increase in price from $\$ 21$ to $\$ 25$, but, since purchasers would fall from 85 percent of persons to 75 percent, revenues would still be maximized at the $\$ 20$ price.

${ }^{2}$ Springfield Telemarketing conducted the survey for us.

${ }^{3}$ We did not ask if they would take the good if we paid them.

${ }^{4}$ Due to a coding problem, this estimate may be too low and we are having the survey firm check the responses here. When corrected, the number may be somewhat higher than that in the text, but only moderately so.

${ }^{5}$ Some respondents refused to answer these questions and some gave inconsistent answers saying, for instance, that they would buy the cheaper product no matter what and then saying they would pay extra for the product made under better conditions. We made the conservative assumption that anyone who refused to answer or who gave an inconsistent response would not pay a premium for a product made under good conditions or would buy the product under poor conditions. But had we deleted these observations, our results would be qualitatively the same.

${ }^{6}$ Since we did not specify the conditions under which the alternative product was made, this is an inference from responses to the two sets of questions. The design that would provide a test of this inference would be to ask consumers to compare a product made under good conditions with one made under positively bad conditions (at varying prices) and a product made under good conditions with one made under unknown conditions. Our analysis compared bad conditions with unknown conditions and good conditions with unknown conditions.

${ }^{7}$ Under pressure from Global Exchange and other activist groups, Starbucks agreed to sell "Fair Trade" coffee beginning in Fall 2000, with guarantees that the coffee comes from cooperatives where farmers earn a reasonable price. This could provide the natural experiment.

${ }^{8}$ The most famous experimental game, the Prisoner's Dilemma differs from the standards problem since it requires both persons to cooperate, but it shows the same thing: that many people do not follow the pure maximizing strategy. The rational response in a fixed period PD game is to defect, but in fact people frequently choose to cooperate.

${ }^{9}$ With suitable interpretation of variables, votes rather than prices, for instance, the same model applies to the potential catalytic effect of activists on governments.

${ }^{10}$ Beyond that point the marginal increase in price is less than the marginal increase in cost while before that point the marginal increase in price exceeds the marginal cost.

${ }^{11}$ We distributed 45 surveys at the USAS National Organizing Conference in July and sent emails to an additional 140 activists listed on the USAS listserver or suggested by respondents. We obtained 39 responses from persons at the Conference and 55 from those sent the email instrument, giving 94 responses and an overall response rate of slightly over 50 percent. 
${ }^{12}$ The questions were identical because we asked the activists questions from the American Freshman survey regarding attitudes and goals.

${ }^{13}$ But sweatshops are also coming back in the United States; Weil (2000) and Duong (2000).

${ }^{14}$ This is a model not addressed here, in which activists try to organize alternative markets by linking consumers in rich countries to producers in poor countries who are paid premium prices for indigenous products such as coffee, tea, bananas, or local handicrafts. In addition to its work with the FLA, the International Labor Rights Fund is one such group; others are listed in the appendix..

${ }_{15}$ An ILO report (1998) on corporate codes and social labels surveyed 200, while the Investor Responsibility Research Center (Varley 1998) collected 121 codes from a survey of the S\&P 500 companies and 80 retailers. Activists recognize that their main success has been in putting labor standards on the world policy agenda. In our survey of USAS activists, 94 percent rated their campaign as very or somewhat successful in increasing public awareness and 90 percent rated their campaign as very/somewhat successful in increasing student activism.

${ }^{16}$ PVH's Bruce Klatsky demonstrates a strong personal commitment to human rights through his work with Human Rights Watch and Kathie Lee Gifford demonstrated concern for the well-being of children through her charitable contributions to children's causes.

${ }^{17}$ For an alternative view of the benefits of "open standards" and competition among monitoring agencies, see Sabel, O’Rourke, and Fung (2000).

${ }^{18}$ Of course, given the paucity of such products in the market today, there is little cost attached to the promise and the true test will come when more final consumers have the choice before them.

${ }^{19}$ Concerns about the effects of codes on homeworkers were raised by Southern NGOs in a workshop organized by NGOs participating in the Ethical Trade Initiative in the United Kingdom (see www.cafod.org.uk/policyviews.htm). Concerns have also been raised about the impact of the agreement to create stitching centers for the production of soccer balls in Sialkot, Pakistan. Shifting production from homes to centralized locations facilitates monitoring of the agreement to end child labor, but makes it difficult for some adult women to earn income because they cannot leave home (see the Clean Clothes Campaign website at www.cleanclothes.org).

${ }^{20}$ For example, Columbia University Professor Jagdish Bhagwati argued in The Financial Times (May 2, 2000) that, "[A] minuscule minority of students who are captive to unions such as the apparel industry's UNITE, have used the language of 'social responsibility' towards the poor countries, to advance an agenda, both illegitimate and narrow, that will in fact harm the very countries and workers they claim to assist." Bhagwati also served on the steering committee of the Academic Consortium on International Trade, which in September 2000 delivered a letter from academic economists to the presidents of universities targeted by USAS expressing similar, though less virulent, concerns.

${ }^{21} \mathrm{http} / / /$ web.mit.edu/krugman/www/. "A policy of good jobs in principle, but no jobs in practice, might assuage our consciences, but it is no favor to its alleged beneficiaries."

${ }^{22}$ See Lynda Yanz, "Constructing Codes from the Ground Up" in Carnegie Council on Ethics and International Affairs, Human Rights Dialogue, Fall 2000, series 2, no 4, p 6 
${ }^{23}$ See http://www.lafollette.wisc.edu/livingwage/ Final_Report/report.htm. A considered defense of a living wage can also be found in a student dissent to the May 2000 University of Michigan task force report on labor standards "The Final Report of the Advisory Committee on Labor Standards and Human Rights," University of Michigan, May 2000. Available on the University of Michigan website.

${ }^{24}$ Most child labor, for example, occurs in agriculture, construction, and domestic services, where anti-sweatshop campaigns cannot readily reach.

${ }^{25}$ Medea Benjamin, Interview, Carnegie Council on Ethics and International Affairs, Human Rights Dialogue, Fall 2000, series 2, no 4, p 7

${ }^{26}$ A conference report from the workshop is available from the Catholic Agency for Overseas Development (CAFOD), at www.cafod.org.uk/policyviews.htm.

${ }^{27}$ The text of the bilateral agreement may be found on the Department of Commerce's Market Access and Compliance website (http://www.mac.doc.gov).

${ }^{28}$ See the NLC's campaign to help workers at the Mil Colores workers plant in Nicaragua.

${ }^{29}$ For an excellent history of the anti-apartheid movement, see Massie (1997).

${ }^{30}$ A description of the FSC may be found at http:/www.panda.org/forests4life/certify_fsc.cfm (last visited on June 9, 2000). See also the FSC homepage at www.fscoax.org.

31 The World Wildlife Fund is now trying to replicate the FSC's success with a Marine Stewardship Council to certify fish products as having been sustainably harvested [see www.msc.org].

${ }^{32}$ IKEA asked its suppliers of solid wood products to ensure that none of their wood came from uncertified old-growth forests by September 2000. A second phase will extend the same requirement to suppliers of other wood products, including paper, cardboard, and furniture made with particleboard, but no target date has been set. See Greenpeace, November 24, 1999 (available at www.greenpeace.org/\%7Eforests/reports/Re-Source/ikeaarticle.html last visited, June 8, 2000). IKEA sales are from their website, www.ikea.com, last visited June 8, 2000; Home Depot sales are from Journal of Commerce, November 12, 1993, 9A.

33 The FSC website (www.fscoax.org) has a list of certified areas; see also UN Food and Agricultural Organization's annual report for 1999. Recognizing the lagging progress in developing countries, the World Wildlife Fund joined the World Bank in an alliance to promote sustainable forestry management globally, with a target of 200 certified hectares by 2005, evenly divided between temperate and tropical forests. 
Appendix Exhibit A: Transnational Labor Rights Activist Organizations

\begin{tabular}{|c|c|c|c|}
\hline & Specialization & $\underline{\text { Year formed }}$ & Orientation \\
\hline $\begin{array}{l}\text { American Friends Service Comm } \\
\text { (http://www.afsc.org/) }\end{array}$ & $\overline{\text { US; Mexico }}$ & $\overline{1917}$ & religious \\
\hline $\begin{array}{l}\text { Asian Immig Women Advocates } \\
\text { (http://www.corpwatch.org/feature/hitec }\end{array}$ & $\begin{array}{l}\text { US Asians } \\
\text { h/aiwa.html) }\end{array}$ & 1983 & ethnic \\
\hline $\begin{array}{l}\text { Asian Law Caucus } \\
\text { (http://www.asianlawcaucus.org/) }\end{array}$ & US Asians & 1972 & ethnic \\
\hline $\begin{array}{l}\text { As You Sow Foundation } \\
\text { (http://www.asyousow.org/index40.htm) }\end{array}$ & shareholder activism & 1992 & do-gooder \\
\hline $\begin{array}{l}\text { Bangor Clean Clothes Campaign } \\
\text { (http://www.bairnet.org/organizations/pi }\end{array}$ & $\begin{array}{l}\text { code of conduct } \\
\text { ica/cleanclo.htm) }\end{array}$ & 1997 & do-gooder \\
\hline $\begin{array}{l}\text { Campaign for Labor Rights } \\
\text { (http://summersault.com/ agj/clr/) }\end{array}$ & general & 1995 & left \\
\hline Coalition for Justice in Maquiladoras & Mexico & 1989 & do-gooder \\
\hline $\begin{array}{l}\text { CISPES } \\
\text { (http://www.cispes.org/) }\end{array}$ & El Salvador & 1980 & left \\
\hline $\begin{array}{l}\text { Co-Op America } \\
\text { (http://www.coopamerica.org/) }\end{array}$ & general & 1982 & do-gooder \\
\hline $\begin{array}{l}\text { Council for Economic Priorities } \\
\text { (http://www.cepnyc.org/) }\end{array}$ & code/monitoring & 1969 & do-gooder \\
\hline Edenwald Gunhill Center & Nike & 1997 & left \\
\hline $\begin{array}{l}\text { Fair Trade Federation } \\
\text { (http://www.fairtradefederation.org/) }\end{array}$ & codes/labels & 1996 & do-gooder \\
\hline $\begin{array}{l}\text { Free the Children USA } \\
\text { (http://www.freethechildren.org/main/in }\end{array}$ & $\begin{array}{l}\text { children } \\
\text { dex.html) }\end{array}$ & 1995 & do-gooder \\
\hline $\begin{array}{l}\text { Global Exchange } \\
\text { (http://www.globalexchange.org/) }\end{array}$ & general & 1988 & left \\
\hline $\begin{array}{l}\text { Global Kids } \\
\text { (http://www.globalkidsinc.org/) }\end{array}$ & children & 1989 & do-gooder \\
\hline $\begin{array}{l}\text { Human Rights Watch } \\
\text { (http://www.hrw.org/) }\end{array}$ & Mexico, Guatamala & 1978 & do-gooder \\
\hline $\begin{array}{l}\text { Human Rights for Workers } \\
\text { (http://www.senser.com/) }\end{array}$ & general & 1996 & do-gooder \\
\hline $\begin{array}{l}\text { Interfaith Center for Corp Resp } \\
\text { (http://www.domini.com/ICCR.html) }\end{array}$ & shareholder activism & 1971 & religious \\
\hline $\begin{array}{l}\text { International Labor Rights Fund } \\
\text { (http://www.laborrights.org/) }\end{array}$ & football; Rugmark & 1986 & do-gooder \\
\hline Justice Do it NIKE! & Nike & $1996 ?$ & \\
\hline La Mujer Obrera & El Paso & & left \\
\hline Labor Defense Network & sweatshops & 1997 & do-gooder \\
\hline LA Jewish Comm for Worker Justice US & & 1997 & religious \\
\hline $\begin{array}{l}\text { National Consumer League, } \\
\text { Child Labor Coalition } \\
\text { (http://www.natlconsumersleague.org/) }\end{array}$ & children & 1989 & do-gooder \\
\hline $\begin{array}{l}\text { National Labor Committee } \\
\text { (http://www.nlcnet.org/) }\end{array}$ & Central America & 1981 & left \\
\hline $\begin{array}{l}\text { NY State Labor-Religion Coalition } \\
\text { (http://www.labor-religion.org/) }\end{array}$ & codes & 1980 & religious \\
\hline $\begin{array}{l}\text { Nicaragua Network Education Fund } \\
\text { (http://summersault.com/ agj/nicanet/in }\end{array}$ & $\begin{array}{l}\text { Nicaragua } \\
\text { dex.html) }\end{array}$ & 1980 & left \\
\hline People of Faith Network & general & & religious \\
\hline
\end{tabular}


(http://www.users.cloud9.net/ pofn/)

Press for Change

Nike

left

(http://www.nikeworkers.org/)

Resource Center of the Americas

Latin America

1991

do-gooder

(http://www.Americas.org/)

Rugmark Foundation USA

child labor/carpets

1995

do-gooder

( http://www.rugmark.org/)

STITCH

Guatamala

1992

left

Support Committee

Mexico

do-gooder

for Maquiladora Workers

(http://enchantedwebsites.com/maquiladora/index.html)

Sweatshop Watch

general (mainly US)

1995

do-gooder

(http://www.sweatshopwatch.org/)

Transnational Resource

Nike

1996

do-gooder

and Action Center (Corporate Watch)

(http://www.corpwatch.org/)

Transfair America

coffee;Starbucks

1996

do-gooder

(http://www.transfairusa.org/)

UNITE (union)

apparel

1994

left

(http://www.uniteunion.org/)

US/Guatemala Labor Education

Central America

$1997 ?$

left

(Now US Labor Education in the Americas Project)

(http://usleap.org/)

USAS

(http://www.umich.edu/ sole/usas/)

Verite

college apparel

1997

left

(http://www.verite.org/)

Vietnam Labor Watch

(http://www.saigon.com/ nike/)

Witness for Peace

China, Asia

1995

do-gooder

NIKE, Vietnam

1996

do-gooder

(http://www.witnessforpeace.org/)

Witness Rights Alert

Central America

1983

left

(http://www.oddcast.com/witness/)

human rights groups 1992

do-gooder

Source: Global Exchange, A directory of US anti-sweatshop organizations; internet search. 